\title{
Exploring the role and importance of human capital in resilient high performing organisations- evidence from business clusters
}

Article

Accepted Version

Pereira, V., Temouri, Y. and Patel, C. (2020) Exploring the role and importance of human capital in resilient high performing organisations- evidence from business clusters. Applied Psychology, 69 (3). pp. 769-804. ISSN 1464-0597 doi: https://doi.org/10.1111/apps.12204 Available at https://centaur.reading.ac.uk/83709/

It is advisable to refer to the publisher's version if you intend to cite from the work. See Guidance on citing.

To link to this article DOI: http://dx.doi.org/10.1111/apps.12204

Publisher: Wiley

All outputs in CentAUR are protected by Intellectual Property Rights law, including copyright law. Copyright and IPR is retained by the creators or other copyright holders. Terms and conditions for use of this material are defined in the End User Agreement. 


\section{CentAUR}

Central Archive at the University of Reading

Reading's research outputs online 


\title{
Exploring the Role and Importance of Human Capital in Resilient High Performing Organisations- Evidence from Business Clusters
}

\begin{abstract}
:
This paper investigates and explores the link between the resilience of organisations, its human capital and firm performance. We base our analysis on the resource based view of the firm, cluster strategy and conservation of resources theories. Our contribution is contextualized by comparing the performance of business clusters across two observational periods, namely pre-recession (2005-2007) and recession (2008-2009) period. We identify six relevant indicators from the extant literature that capture economic dynamism, human capital and financial viability of firms in order to capture the performance across clusters and capture resilience to the global financial crisis. We contribute by identifying organisations in business clusters that perform better due to being more resilient, particularly during challenging times. Through triangulation we find overwhelming evidence of the overarching role and importance of human capital (people) in driving more successful organisations in business clusters as they possess greater resilience during challenging times such as the recent global financial crises. We show that strong clusters not only improve regional employment and turnover growth over time, but improve resilience of regional economies to downturns through resource gain and crossover processes. We further illustrate that understanding the impact of resource reservoirs, resource passageways and crossover provides a framework for further research and intervention to promote resilience in organisations.
\end{abstract}

Key words: Resilience, Business-Clusters, Conservation-of-Resources Theory, GlobalFinancial-Crises, Resource-Based-View, Firm Performance. 


\section{INTRODUCTION}

There is a wealth of academic research in the psychology literature on harnessing resilience in times of crises (Sutcliffe \& Vogus, 2003; Klein, Nicholls \& Thomalla, 2003; Manyena, 2006; Carmeli \& Markman, 2011; Linnenluecke, 2015). Resilient organisations and its people thrive in uncertain, unstable and many other adverse situations (Lengnick-Hall, Beck \& Lengnick-Hall, 2011; Hamel \& Valikangas, 2003; Hitt, Keats \& DeMarie, 1998). For example, the psychology literature has examined, in detail, resilience as a resource for coping (c.f. Braunsteisn-Bercovitz, Frish-Burstein \& Benjamin, 2012; Carmeli, Friedman \& Tishler, 2013; Carmeli \& Gittell, 2009; Kossek \& Perrigino, 2016). Scholars also refer to resilience as a combination of a trait, process and capacity with an emphasis on the individual level (Fredrickson, 2001; Carmeli, Yitzhak-Halevy \& Weisberg, 2009; Liu, Wang \& Lu, 2013; Stephens, Heathy, Carmeli, Spreitzer \& Dutton, 2013; Williams \& Shepherd, 2016). Others have defined it as a capacity to bounce back from adversity, uncertainty, failure, conflict or even positive change (Luthans, 2002; Shepherd, Wiklund \& Haynie, 2009). In fact, led by the work of Luthans (2002) and his colleagues, resilience has emerged as a one of the core dimensions of psychological capacity (Youssef \& Luthans, 2007).

However, much less has been written about 'organisational resilience', which is a relatively new term in the management literature to indicate a much broader concept of resilience as a value driver for an organisation and its people (Ferris, Sinclair \& Kline, 2005; Ollier-Malaterre, 2010). It enables businesses to harness experience and embrace opportunity in order to prosper in today's dynamic, interconnected and uncertain world (Junni, Sarala, Taras, \& Tarba, 2013; Jansen, George, van Den Bosch \& Volberda, 2008). Despite its growing importance not much is known about the mechanisms through which organisations develop resilient capabilities (Kossek \& Perringino, 2016).

Although the individual level research on resilience is influenced by the higher level social environment in which employees are embedded in, the broader societal context (e.g. country, regional or industry differences) and its influences have been neglected in the literature. In terms of the rationale for studying 'business clusters' in the context of this study, we make the following arguments that link to the special issue topic and call for papers. We hypothesize that factor conditions that are essential in a cluster, are the pool of specialized and skilled employees present in a cluster, i.e. its people. For example, engineers, IT specialists, R\&D scientists their career decisions on opportunities to earn the highest reward that also satisfies their level of prestige and accomplishment. In this sense, world-leading 
business clusters have the strong ability to attract and sustain key personnel who hold positions that are prestigious and are well rewarded. In events of crises, the supply of specialized workers with highly-relevant industry-specific training will increase, as such workers will seek employment in such business clusters with higher returns and less risk of losing their employment due to a crisis. In other words, the global financial crisis may have led to a move of highly skilled workers from non-cluster to cluster locations, which potentially strengthens the cluster in its resilience. It is under these circumstances that investigating and exploring the links between resilience in organisations and its people to cluster performance in the knowledge economy is a compelling and interesting area to studyand hence our principal research question. More specifically our two research questions are examined through a dual methodological strategy. One, quantitatively we investigate and explore our first research question (phase one), and two, we further investigate the results from our quantitative method qualitatively through a triangulated in-depth method of interviews with key managers in similar organisations/industries within the identified successful clusters (phase two). Our research questions are as follows:

1. Which originations in business clusters show evidence of being more resilient, through their performance over time, particularly during the recent global financial crisis? (quantitative analysis- phase one)

2. What is the role and importance of human capital (people) in driving organisations to be more resilient than others in business clusters during challenging times such as the recent global financial crises? (quantitative and qualitative analysis- phase two)

Furthermore, questions remain as to the identity of some of the key factors that promote wider societal level resilience. There is also a need to explore some of the differences as well as commonalities regarding organisational/societal resilience between emerging and developed economies. For example, a recent shock event that affected nearly the entire world was the global financial crisis of 2008. Different industries, sectors, economies and clusters reacted in varied ways in order to survive and eventually bounce back from the recession. The presence of clusters in a country could have had differing effects on regional economies during the crisis. On the one hand, agglomeration economies arise in regions specialized in strong clusters (see e.g., Delgado, Porter, and Stern, 2010, 2014; Glaeser and Kerr, 2009; Porter, 1998; Feldman and Audretsch, 1999). The presence of strong clusters in a region could have made the industries operating in the clusters and the regional 
economy more resilient to the crisis. On the other hand, cluster specialization could have also increased a region's vulnerability to crisis when related industries are more intertwined together with the length and depth of the crisis (Acemoglu et al., 2013).

Much of the evidence is, however, based on in-depth case study analysis which generally explains the success of clusters through a combination of historical events that has aided in the simultaneous cooperation and competition amongst firms across the value chain in a particular industry, sometimes with the help of government support or public private partnerships, such as industry and university relationships. What has traditionally been missing in this literature is more quantitative evidence about the resilient performance of organisations within and across business clusters. Does being part of a cluster help firms and its employees develop resilience to keep a steadier performance? What aspects of business clusters make some of them more resilient than others? These questions are left largely unanswered by the existing literature.

Thus, by borrowing the lens from resource based view of the firm (RBV), cluster strategy thinking and conservation of resources (COR) theories, we examine the link between organisation/people resilience and firm performance in the context of business clusters in the pre-recession (2005-2007) and recession (2008-2009) periods. The paper contributes through a two-phase methodological strategy. In the first phase, we use a quantitative analysis that compares 80 business clusters around the world. This analysis builds on our previous work on business clusters (Temouri, 2012) by integrating our findings with a conceptual framework and complementary qualitative analysis. We measure six relevant indicators (growth rates of young firms, employment, turnover, profitability, liquidity and solvency) to measure the relative performance of the business clusters. In the second phase, we use a qualitative analysis by interviewing key managers in organisations that operate in the identified resilient business clusters. This allows us to analyse relative business cluster performance from various important dimensions. For example, we can distinguish certain clusters that are better in generating higher turnover growth that leads to new jobs or which clusters are generating more successful young firms or which entrepreneurial clusters are also the ones that grow the fastest and why? In distinguishing between the pre-recession versus recession period, we are also able analyse the impact of the worst economic crisis since the Great Depression of 1929 on the performance of business clusters. Our analysis shows which indicators have declined the most and which ones have kept a better-than-average performance in an attempt to find out which business clusters have been more resilient during the recession. 
By examining the above macro resilience indicators using the lens from RBV, cluster strategy thinking and COR theories, we aim to contribute to the organisational / people centric resilience literature in four pivotal ways. First, we examine multiple conceptual strands related to accessing resources (trait i.e. entrepreneurialism, capacity i.e. employment growth and turnover growth and processes i.e. resource gain and crossover) within the context of business clusters in the knowledge economy in the aftermath of financial crisis that are not mutually exclusive, but holistic. Second, we explore and propose that to create and sustain resilience at business cluster level within the knowledge economy, shared resource accumulation as well as spillovers are important. Third, we contribute by integrating the crossover model as a mechanism for applying COR theory to macro organisational level entities such as clusters we enrich our understanding of the passageways leading to organisational resilience. Finally, we contribute by developing both a theoretical and methodological framework in examining business cluster resilience. We do so by linking varied strands of the literature and cross-disciplinary theories.

\section{THEORETICAL FRAMEWORK}

Our theoretical framework incorporates four strands of literature, namely the RBV, COR, cluster theories which are each discussed in terms of the resilience literature. We begin our discussion with an overarching link between the capacity for collective resilience and business clusters, before moving to the links between RBV, COR, cluster and resilience literatures.

\section{Capacity for Collective Resilience and Clusters}

The relationship between resilience at individual level and organisational/societal level reflects the interaction between a macro system and micro sub-systems. This interaction, however, is not a mere aggregation of individual concepts at organisational level but rather a complex and interdependent web of network that allows the organisation to develop a capacity for resilience, which is a very important characteristic in clusters (Lengnick-Hall et al., 2011; Morgeson \& Hofmann, 1999, Delgado, Porter, and Stern, 2015).

Our review of the existing research on organisational resilience suggests that it generally descriptive in nature and outcome focused (e.g., Coutu, 2002; Horne, 1997; Horne \& Orr, 1998; Mallak, 1998 a, b). Whilst there is certainly the element of risk prevention, mitigation and continuous performance in organisations and its peoples' resilience, it is equally focused on business improvement and is not a defensive strategy. Beyond the 
effective transactional and day-to-day operational capability and short-to-medium term ability to adapt and change, resilient organisations have a tendency and a unique ability to shape the business environment positively both within and outside their own organisation (Shin, Taylor, Seo, 2012). For example, we argue that in the cluster context, it could be an ability to strategically collaborate with its suppliers and improving the overall management of their business. These deliberate attempts are undertaken to benefit the organisation and to earn success at both individual level and collectively across the value chain. Further, when it comes to improved CSR practices, the benefits even extend to the communities in which the organisations operate.

Prior evidence seems to suggest for these positive effects of resilience at cluster level. For example, there is evidence (e.g., Saxenian, 1994; Kranton \& Minehart, 2000; Helper, MacDuffie, Sabel, 2000) that firms can respond well in ambiguous situations if their regions have more flexible supplier-buyer networks compared with vertical integration. Thus, these types of inter-firm collaborations are more likely in stronger regional clusters and could be reinforced during a crisis or challenge. Relatedly, there has been is qualitative evidence that firms can benefit from social networks and altruism among cluster firms during a crisis. For example, in the mechanical engineering clusters in Germany, firms experienced a more positive employment trend during 2008-2009 that was in part facilitated by memberships into cluster organisations (Wrobel, 2013). In the longer term, strong clusters can diversify into new (related) activities in response to shocks. Delgado et al. (2015) examined the relationship between resilience and clusters of related industries in the US during the global financial crisis using aggregate data, and found that industries experience a higher employment growth when located in a region where other related industries are represented. This contributes in explaining the resilience of Silicon Valley (Saxenian, 1994; Bresnahan and Gambardella, 2004) and the re-invention of the media cluster in Leipzig, Germany (Bathelt and Boggs, 2003).

Van den Berg, Braun \& Van den Meer (1997) expound that clusters can contribute to the organising capacity of regions by building upon the strategic networks and linking the private and public sectors, key individuals and collective processes providing vision, leadership and political as well as broad societal support. They further inform that such organising capacity can help regions deal with spatial-economic problems and obstacles by collaborating thereby reducing the barrier for otherwise isolated actors to team up for a common cause. Despite, this attention it is safe to say that such an organising capacity of clusters has not been examined with respect to pre- and post recession external contingencies 
with respect to emerging versus developed economies.

This paper will therefore delve into how organisational resilience is a dynamic phenomenon that occurs within and across temporal stages. To do so, we identify three dimensions from which we derive six organisational indicators to measure how they differentially impact on cluster performance outcomes. The three dimensions of human capital, economic dynamism and financial viability are derived from the literature on cluster theory which highlights the importance of the superior labour pool and highly skilled employees in clusters (Porter, 2000; Malmberg \& Power, 2005), the higher productivity and innovation levels of cluster firms (Batista and Swann, 1998; Rocha, 2004; Karaev, Koh \& Szamosi, 2007; OECD, 2010) and the access to superior networks for collaborations, including sourcing of finance (Lee, 2009). The role and importance of human capital when it comes to resilience of organisations during challenging times has been well documented in the extant literature (Pereira and Malik, 2015; Malik, Pereira \& Budhwar, 2017). Of the three dimensions identified above, the straightforward argument that can be made is that both economic dynamism and financial viability are dependent on the quality of human capital. Recent research by Driffield, Pereira and Temouri (2017) have shown through a 19-year longitudinal dataset that even though jobs are outsourced from developed to developing countries, organisations showed resilience in showing little impact on employment at home during the 2008 global financial crisis. We therefore, a priori, take this as our premise and test this argument. In doing so we build upon and develop the literature on the role and importance of people within organisation in the context of resilience.

\section{Resource Based View and Resilience}

The resource based view describes specific characteristics that a firm deliberately develops as desirable resources or strategic assets. Such desirable resources are outlined by Barney and Wright (1998) using their VRIO framework. This framework can be used to argue that organisations and its people need to create 'Value' in terms of either diminishing costs or improving revenues. This is especially relevant in the context of being resilient through its people in challenging times, such as the global financial crises. 'Rareness' (R) is seen as the capability of organisations to develop and exploit idiosyncratic traits and dimensions of the firm's human capital in order to obtain competitive advantage, again by portraying 'rare' characteristics of being resilient. 'Inimitability' (I) or the difficulty of copying a rival's firms competitive advantage is achieved by organisations' executives by developing and nurturing traits and dimensions of the firm's human capital which in turn are resilient in challenging 
times. Lastly ‘Organisation' $(\mathrm{O})$ concentrates on collective systems, instead of lone practices, where practices are optimised when they exist as a coherent system, thus offering resilience during challenging times.

Further, within the RBV argument above, resources by being resilient during challenging times, will not be as valuable if they are able to be imitated with ease. Barriers to imitation include concepts such as idiosyncratic timing and learning; path dependence; first mover advantages and organisational learning through speed and experience; social complexity; and causal ambiguity. The latter two are coming to the fore more recently in the literature and are also relevant to our theoretical focus of social complexity where the evolution of networks and relationships is important. People work collectively internally and externally across organisations to develop social capital but in the face of uncertainty and causal ambiguity which some organisations are able to manage in a manner that creates competencies of being resilient.

Building on the concept of RBV of the firm, Hamel and Prahalad's (1994) concept of 'core competencies' is defined as a unique set of skills, knowledge and technologies that enables an organisation to provide certain rewards and gains to clients and customers. They argue that these are not only specific to a firm's products and services but represents the amalgam of learning across individual skills and knowledge bases and organisational subunits, and that these must be competitively idiosyncratic. They argue that such competencies should be core not just as an asset (as defined in accounting), but should represent a 'broad opportunity arena' or 'gateway to the future'.

Further, within the RBV, there is also an emphasis on the evolving knowledge-base rather than product-base, when it comes to the very basis of a firm. Here, whatever the terminology, whether human and/or social capital, these should clearly be a crucial or key aspect of an organisation's special or 'core' competencies, and this can be achieved by developing VRIO resilient behavior and characteristics. Lastly, when it comes to the application of the RBV, Leonard (1998) develops four dimensions of 'core capability', that includes , human capital knowledge and skill; physical and technical processes and systems; managerial practices and systems; and values, believes and norms. Leonard's model further illustrates the human capital implications more clearly wherein every existing and current positive strength can eventually turn into a weakness and that there is an evolving and persistent renewal that becomes a necessity to avoid getting into the cycle or habit of 'core rigidities'.

Overall, when it comes to the strategy of competitive advantage through firm 
capabilities, the RBV prescribes a focus on the uniqueness of know-how of firms, which includes the technical as well as managerial aspects. Further, such know-how focuses on both, the creation as well as exploitation of knowledge and organisational learning.

In this context, the knowledge-based view (KBV) of the firm is an important approach within the RBV, as its central tenet is that although firms differ in their knowledge level and intensity, wherein a few firms would operate and perform better by possessing a fairly uniform and stable know-how, whilst others firms operate in greater knowledgeintensive conditions. For all firms, however, the environment can change, such as in our research context the $2008 \mathrm{GFC}$, and the key therefore is an important question- how do firms build their absorptive capacity for learning, or in other words the firm's 'dynamic capability' (Teece et al., 1997), which we could link here to 'resilience'. Research by Hervás-Oliver \& Albors-Garrigós (2007) has shown that the RBV lens can be applied in an empirical setting to evaluate cluster performance.

\section{Conservation of Resources, Caravan Passageways and Resilience}

Organisational resilience is not a static phenomenon, it is something that can be built or diminished over time (Olcott and Oliver, 2014, Ambulkar, Blackhurst \& Grawe, 2015). Therefore, the concept of regrowth, regeneration and recovery are not alien following adversity with respect to understanding resilience. An individual level motivational theory that can help to illustrate this process of resource regeneration in the context of crises is conservation of resources theory (Hobfoll, 2002). The basic premise of COR theory is that individuals possess 'resilient' qualities wherein they strive to obtain, retain, foster, and protect these central values. This means resilient employees engage in these vital "resources in order to conduct the regulation of the self, their operation of social relations and how they organize, behave and fit into the greater context of organisations and culture itself" (Hobfoll, 2011:117) COR states that even when stress (or external contingencies) are not taking place, "people are motivated and directed biologically, socially, cognitively and culturally to lead their resources to obtain, retain and protect their resource reservoirs" (Chen, Westman and Hobfoll, 2015: 97). The three core principles of COR are as follows. Initially, as a first step, to identify that resource-loss is inexplicably more prominent than resource-gain. Second, individuals must invest in these resources in order to protect against such resource-loss, and at the same time recover from losses by gaining such 'resilient' resources. Next, individuals with greater resources but naturally possess qualities that are less vulnerable to resource-loss and more capable of scoring high on resource-gain. Contrariwise, those with scarcer 
resources are more vulnerable to resource-loss and averse to resource-gain. Third, there is a natural tendency for resource-gain increases in reputation and importance when resource-loss has been greater and enduring. In the resilience process the main emphasis of COR, as resource loss asserts a key role for resource gain.

"Resilience is first and foremost a property of environments that are a) rich in personal, social, material and energy resources b) allow access to those resources and c) provide safety and protection against resource loss and promote resource gains" (Hobfoll, Stevens \& Zalta, 2015: 4). These environmental situations are best understood with help of caravan passageways, which are defined as "the environmental conditions that support, foster, enrich, and protect the resources of individuals, families, and organisations, or that detract, undermine, obstruct, or impoverish people's resource reservoirs" (Hobfoll, 2012, p.229). Bonanno, Romero and Klein (2015) study on resilience within individuals, families and communities, demonstrates that individuals inherit richer collections of resources and have more opportunities to develop by simply living/residing within enhanced and steady caravan passageway of resources. Meaning, those having access to rich resource environments ultimately accumulate more resources than those in resource poor environments. Richer environments leads to gains versus poorer environments which lead to resource loss. However, an important element of this resource gain and loss spiral is that, according to Hobfoll et al., (2015), resource loss is more rapid and powerful than resource gains as accumulation of resource gains requires capacity building. The inference of such a dynamic suggests that severe resource loss events such as recession in this case, will greatly undermine resilience building capacity of firms. Moreover, given the spiraling nature of loss cycle, initial resource losses may trigger in an immediate effect rapid likelihood of further loss, undermining the resilience building capacity of organisations/firms. This would be the most likely outcome unless a rich resilience pool of protective resources has been built prior to the resource loss (Ennis, Hobfoll, Schcoder, 2000). Gains on the other hand require a lot more time, effort and energy, essentially moving at a sluggish pace. This means that building resilience is developmentally a much slower process without the resource rich passageways.

The importance of loss and gain spirals is mitigated through an initial resource gain which begets future gain, thus generating 'gain spirals'. For example, an individual level resource that leads to resilience is self-efficacy which refers to the belief in one's capabilities to organize and execute the courses of action required to manage prospective situations (Bandura, 1995). At individual level efficacy belief is likely to have an impact on the way employees cope with stressors at workplace but at group level, efficacy belief may lead to 
resilience as a strong sense of collective efficacy (Benight, 2004; Chen \& Bliese, 2002; Jung \& Sosik, 2003; Stajkovic, Lee, \& Nyberg, 2009) contributing to a positive interpersonal climate and greater cooperation and helping among group members. The same can be true when applied at regional/local or societal level. By providing a form of 'psychological immunity' local clusters can help attain operational, behavioral as well as strategic assistance as one of the many aspects of repertoire of resources that organisations can utilize to cope with external contingencies.

Because much of positive psychology discussion on resilience focuses on individuals, researchers have ignored this critical aspect of context with respect to macro organisational resilience. Zautra, Hall, and Murray (2010) argue, that the concept of organisation resilience is applicable multidimensional to individuals, teams and societies, and that a resilient organisation is argued to be crucial in creating passageways that conduce and contribute in boosting resilience and containing destructive, loss-generating aspects of the work environment. Thus, within organisational situations, resource investment depends largely on the collective resources available within that organisational ecosystem and both individuals' and groups' abilities to gain those resources. This links to the notion of resource caravans within COR theory (Hobfoll, 2002). Therefore, in that sense, successful clusters may be able to offer organisations a community of shared resources; imbue their departments, sections, managers and employees with resources; and facilitate the internal transaction of resources to meet the clusters' mission. Thus, resources of value, as explained in the 'valuable' of the VRIO framework of RBV (Barney and Wright, 1998), may be exchanged and within successful high profile organisations of certain clusters, maybe able to enjoy the special status of use of these resources. Cluster support, stability as well as safety are all the dimensions of resource caravans creating, sustaining community level ecologies (the 'rareness' and 'inimitability' of the VRIO framework). These ecologies can be seen to be creating passageways in which resources are supplied, protected, shared, fostered and pooled ('organisation' of the VRIO framework). It is also important to emphasize the network features that make cooperative links between individuals and firms a resilience enhancing element. The crucial point is that groups of individual firms in a cluster have incentives to work on joint innovation projects or sharing complementary knowledge and information to create synergies for their mutual benefit. Ultimately, this active collaboration across many firms in a cluster defines a competitive landscape which incentivizes all firms to operate at their optimal. This in turn means that any negative shock to the cluster system would undermine such a network system and the support and survival of firms in in the interest of 
every firm in the cluster. This is an additional element of resilience which may be present at a lower level outside clusters.

\section{Conservation of Resources, Crossover and Resilience}

Crossover is defined as an interpersonal process that occurs when something experienced by one entity affects an important aspect of another entity in the same social environment (Westman, 2001). It represents a mechanism by which resources are transferred and exchanged within organisational contexts. In that sense, crossover can be viewed as resource caravans since these can be transferred at inter-individual, specifically dyads, team, organisation as well as community levels. Though there is plethora of research on the topics of 'crossover of psychological stress and strains such as anxiety' (see for example, Westman, Etzion, \& Horovitz, 2004), the topic of 'burnout' (e.g. Bakker \& Schaufeli, 2000; Westman \& Etzion, 1995) and 'work-family conflict' (e.g. Hammer, Allen, \& Grigsby, 1997; Westman, Etzion, \& Gattenio, 2008), there is scarcity within the literature on positive resource crossover and its dynamic influence on resilience.

Thus, though there is an assertion within the COR theory that passageways surge resilience, the crossover model does not validate a crossover of resilience intrinsically by itself, in-fact it is the mechanisms that increase resilience. Comparable to COR, the crossover model suggests that a conventional bundle of resources (resource caravans) augments resilience within work-settings and work-culture and enriches organisations' and clusters' resilience via the crossover-of-resources process. Another important mechanism in the crossover model is that of the notion of common stressor (Westman, 2001; 2013). The idea behind this is that common stressors or contingencies in the shared environment increase strain for everyone involved. In that sense, people or organisations in close exchange of resources share or experience the same stressors from the environment e.g. economic recession. The same is true for positive crossover i.e. the mechanism of positive events and sharing of commonly held resources at organisational or community level may be fundamental to the creation and sustaining of resilient clusters.

(Insert Figure 1 about here)

Figure 1 illustrates both the theoretical and methodological framework in examining business cluster resilience. It shows our conceptual framework as the inner triangle. The three interrelated aspects of the framework are the RBV which relates to COR in the sense that 
both the theoretical models refer to application of bundle of valuable tangible and intangible resources to gain competitive advantage. RBV talks about resources from evaluation criteria i.e. resources being rare, value creating, inimitable and non- substitutable, whereas, COR focuses on resource loss and gain processes. In other words, COR, illustrates the process of value-creation of the resources as mentioned by RBV.

The 'caravan passageways' and 'crossover' are the micro dimensions that highlight the process of this competitive advantage at individual, firm and cluster level. Caravan passageways are the tunnel through which resources travel from creating, aggregation to sustainment of one another. And 'crossover' is the bridge that occurs when something experienced by one entity has an equal and profound effect on another entity from the same social environment. In that sense crossover can be viewed as resource generation process much like caravan passageways (Halbesleben, Neveu, Paustian-Underdahl \& Westman, 2014). The outer circle shows the thematic approach in incorporating three perspectives of business clusters. The first one, is the human capital dimension, which includes the growth of employment in cluster firms and the entrepreneurialism, measured as the share of young firms in the cluster (i.e. 5 years or younger). The second perspective is the economic dynamism dimension which includes the growth rates of turnover and the returns on total assets of cluster firms. The third perspective is the financial viability dimension which includes the liquidity ratio and solvency ratio of cluster firms. These three thematic approaches highlight different and important characteristics of clusters which need to be taken into account to capture and explain organisation/people resilience.

\section{RESEARCH DESIGN}

Our two research questions are examined through a dual methodological strategy.

Quantitatively we investigate and explore our first research question, which we complement and triangulate qualitatively through in-depth interviews with key managers in similar (representative) organisations/industries within the identified successful clusters. Thus, our phase one quantitative analysis includes 80 clusters, half of which are known to have their core activity in the high-tech manufacturing sector (HTM) and the other half are clusters in the knowledge-intensive services activities (KISA) as defined by OECD-EUROSTAT. ${ }^{1}$

\footnotetext{
1 According to the OECD-Eurostat, the following three industries are defined as being HTM: aircraft and spacecraft; pharmaceuticals; office machinery and computers; radio, television and communication equipment; medical, precision, and optical instruments. KISA includes the following three industries: post and telecommunications; ICT, computer and related activities; research and development.
} 
Many business clusters we have identified are located in the United States with nine business clusters; Japan, Germany and Austria with six each; and France and Sweden with five each. We also were able to include three of the leading emerging market countries (Brazil, China, and India) which resulted in a broad set of countries to ensure the international comparability of the business clusters in our analysis.

The identification and inclusion of business clusters followed three main criteria. The first criterion was to ensure that each business cluster has been subject of focus in the relevant literature to ensure reliable and detailed information led to the identification of clusters and avoid regional production systems or large metropolitan areas which cannot be seen as business clusters. As part of this first identification process, we complemented our inclusion of clusters by contacting well known cluster scholars to identify and provide information on such business clusters based on their own academic expertise.

The second criterion was to investigate whether the firm level database at our disposal had sufficient coverage on firms for each business cluster that was identified from the literature. This meant that we tested and verified that the overall number of firms was reasonably close the literature as well as each firm reporting figures for the key variables used in our analysis. Other important considerations were to ensure that each firm's activity is consistent with the dominant economic specialization that the literature identifies this business cluster by.

The third criterion was to ensure that the geography of each cluster is mirrored closely by our database to ensure that we only capture firms that belong to a business cluster location.. This meant that in terms of location of each firm, we used the postcode for each firm to allocate them to their particular municipality. Using the municipality as the unit of analysis is common practice in the cluster literature which allows for the "core" municipalities to be part of the identified cluster. This ensures statistical and economic reliability, such that one captures most of the cluster firms for the statistical analysis as well as ensuring that the majority of the economic activity of the cluster is included according to the information from the existing literature and local government websites.

The research design of identifying 80 clusters from the mostly case-based cluster literature is the most appropriate method to make sure that we truly identity high-technology or knowledge intensive clusters. The literature was invaluable in pinpointing the geographical areas in which these clusters exist. We used this information and merged it to the firm-level data in order to collect quantitative measures that could be used to compare consistent estimates across clusters, which has not been done before in the literature. In terms of the 
methodology, the annual accounts data we have allows us to measure annual growth measures of six indicators. From the outset we wanted to keep these six indicators as close to the literature as possible but also adopt a simple comparison of averages in order to uncover certain trends and tell the story of resilience for clusters. We, thus, created four annual growth rates. The first two annual change rates, 2005-2006 and 2006-2007 were used to capture the pre-crisis period (i.e. 2005-7) and the 2007-2008 and 2008-2009 are used for the recession period (i.e. 2008-9).

\section{Phase one: Quantitative data}

The firm-level data for each business cluster is drawn from ORBIS, a commercially available database offered by Bureau van Dijk. This dataset has been used widely by a growing number of researchers in the economics, management and strategy literatures. The database relies mostly on national statistical agencies and other national administrative sources (for more detail see Ribeiro, Menghinello and De Backer, 2010).

For the purposes of business cluster analysis, the use of ORBIS has two distinct advantages. The first advantage is that the detailed and complete location (i.e. postal address) of each firm is provided,. This allows for better geographical disaggregation than is possible with individual national statistical datasets. The second advantage is that some variables, such as solvency and liquidity are generally not available from national statistical databases. It is this advantage of having access to important variables needed for such a cluster analysis that we discuss next.

\section{The identification of indicators}

The analysis is based on a total of six indicators under the broader three dimensions of human capital, economic dynamism, and financial viability, of which the importance and role of human will be assessed (and is the main focus of our second research question). Each indicator is given for each firms collected from the ORBIS database. At the cluster level, we calculated each indicator as the average value for all cluster firms, which is a common procedure to limit outlier and other biases from aggregating firm level data. The following are the six indicators we have identified:

\section{Human capital}

- Entrepreneurialism: share of young cluster firms (i.e. 5 years or less) 
- Employment growth rate of cluster firms

Economic dynamism

- Turnover growth rate of cluster firms

- Profitability growth rate of returns on total assets of cluster firms

\section{Financial viability}

- Liquidity ratio: current assets / current liabilities of cluster firms

- Solvency ratio: shareholder funds / total assets of cluster firms

\section{Phase two: Qualitative data}

Based on our results from phase one above, in phase two, we further investigate the results from our quantitative method qualitatively through a triangulated in-depth method of interviews with key managers in similar (representative) organisations/industries within the identified successful clusters. Table 1 portrays details of the representative organisations within specific industries wherein we conducted our qualitative in-depth interviews with key managers. We framed the following questions based on results and findings from our quantitative data analysis above. These questions were more grounded in the psychology literature.

- How did your company react/absorb to the external recession shocks?

- What factors facilitated or aided resilience to recession, explain/provide examples?

- How do you think your company/cluster responded to recession compared to other clusters/companies?

- How were they resilient and how being part of the business clusters facilitated that?

(Insert Table 1 about here)

We analysed our qualitative data using content analysis as a means to determine the themes or concepts within the interview data (Solomon, 1993; Weber, 1990). In doing so, we aimed to analyse the presence and meanings of such themes and concepts, to make meaningful inferences about the messages within the available interview data set. More specifically, we looked for and analysed the data through 'conceptual' content analysis as opposed to 'relational' content analysis. Conceptual content analysis was utilised as it helps establish the existence and frequency of concepts represented by words or phrases within the 
text/data. In other words, the concept chosen for examination was the evidence of the role and importance of human capital (people) in driving organisations to be more resilient than others in business clusters during challenging times such as the recent global financial crises. We looked for themes and terms that were both implicit as well as explicit. While explicit terms are easy to identify, coding for implicit terms and deciding their level of implication was complicated, but we based our analytical judgments systematically. We chose our coding with respect to the eight category coding steps indicated by Carley (1990). These sequential steps included deciding the level of analysis (we specifically looked for word, word sense, phrase, sentence, themes that provided evidence of the role and importance of human capital (people) in driving organisations to be more resilient); deciding how many concepts to code for (we stuck with the pre-defined set of categories (our second research question) as it allowed us to stay focused and examine the data for specific concepts; deciding whether to code for existence or frequency of a concept (we coded for the existence of a concept i.e. the importance of human capital (people) in driving organisations to be more resilient); deciding on how we distinguish among concepts (we looked for word segments that fell into similar categories); developing rules for coding our texts (we were consistent and coherent in our codes, and followed a set translation rule); deciding what to do with "irrelevant" information (we ignored common English words like "the" and "and"); coding the texts (we coded our data manually, for ease, and to avoid 'interpretative' error); and analysing our results (we made sure we drew conclusions and generalisations where possible, for greater validity and reliability).

\section{FINDINGS}

We first present our quantitative findings through the rankings of the clusters according to the three dimensions identified by the literature as discussed above, after which we present our qualitative findings.

\section{Findings from quantitative data}

Due to space constraints, we show the tables of rankings only for the first ten and last ten clusters. For full details of results, please refer to the earlier work by Temouri (2012). Tables 2 and 3 show the ranking for the human capital dimensions (with the indicators of entrepreneurialism and employment growth). Table 4 and 5 show the ranking for the economic dynamism dimension (with the indicators of turnover growth and profitability growth). Tables 6 and 7 show the ranking for the financial viability dimension 
(with the indicators of liquidity growth and solvency growth). We now discuss the key quantitative findings of each of the rankings after which we present our qualitative findings. Please note that we have used t-tests to highlight the statistical significance between means for the pre-recession and recession period. Differences in means are all significant at the 5\% level.

\section{Human capital dimension}

\section{Entrepreneurialism}

Overall, table 2 shows that the more resilient clusters tend to have a higher share of young firms, which in this case are the ones that keep similar rates both in times of pre-recession as well as the recession period. The correlation between entrepreneurialism across the two periods is 0.85 in HTM clusters and 0.88 in KISA clusters. Thus, economic recessions seem to be periods of creative destruction, allowing new and young entrants to increase the competitive pressure on the leading and larger incumbent firms. Indeed, in the HTM sector, the top three clusters show higher shares of young firms in the recession period compared with the pre-recession period. The increase in younger firms in the recession period is also the case for the top two KISA clusters who remain in their leading positions. However, clusters such as Heidelberg in Germany fall significantly in the rankings due to lower rates of young firms.

(Insert Table 2 about here)

\section{Employment growth}

Overall, the KISA clusters experienced a significant reduction in the average rate of employment growth (from $24.4 \%$ to $14.3 \%$ ), while HTM clusters have proven more resilient to the recession (from $15.7 \%$ to $11.2 \%$ ). Despite the steep fall, the average rates of employment in KISA clusters outperform the ones in HTM clusters, pointing to the ability of services to create more employment than manufacturing. However, this advantage of generating more service jobs is weakened by a greater propensity to lose them during a recession.

The employment growth experience of several clusters has been volatile between prerecession and recession period. In general, the negative impact on employment during the recession is more pronounced for clusters which observed higher employment growth in the pre-recession years. The reason for this development could be that new jobs were less 
protected by labour legislation or not well integrated in organisations compared to existing jobs. Examples of HTM clusters that did well during the recession LISA (Austria), Saskatoon (Canada) and Oslo (Norway) in the case of HTM. Examples of well performing KISA clusters include the Brazilian Silicon Valley, the Beijing cluster (China) and the Linz cluster (Austria). This highlights that several emerging economies are also among the most resilient in terms of employment during the recession period.

(Insert Table 3 about here)

\section{Economic dynamism dimension}

\section{Turnover growth}

In line with the employment results, KISA clusters outperformed HTM in turnover growth in both periods, albeit the differences are smaller as compared with the employment growth changes. We find a positive correlation between turnover growth and the share of young firms, which suggests that turnover growth has resulted in job creation for many clusters, particularly for KISA clusters pre-recession and to the same extent for KISA and HTM in the recession period.

We find that turnover growth is more volatile in both periods as well as being affected sooner by the negative impact of the recession as compared with employment. Despite significant slowdowns, the majority of the business clusters did not experience negative growth rates in turnover during the recession, which adds another dimension to the evidence of the relative resilience of clusters. Among KISA clusters the fluctuations are less radical than for HTM but still significant.

(Insert Table 4 about here)

\section{Profitability growth}

We know that negative profitability rates are much more common during a recession as compared to other indicators. Thus, our measure of profitability (returns on total assets), is expected to show yet another dimension of cluster experience over time which is different from the performance observed in terms of turnover growth figures. Changes across the two periods are more significant, unlike in the case of entrepreneurialism. This seems to indicate 
that most business clusters struggle to allocate and manage assets to their optimal use during the recession in order to maximize profitability.

(Insert Table 5 about here)

\section{Financial Viability Dimension}

\section{Liquidity ratio}

The HTM business clusters show a larger negative impact of the recession when it comes to average growth rate in liquidity which fell from $0.42 \%$ to $0.36 \%$, whereas the liquidity rate for KISA are much steadier at $0.53 \%$ and $0.51 \%$, respectively. This means that KISA clusters seem to be more liquid than HTM clusters, which is a finding that is also observed for our next indicator, which is solvency.

(Insert Table 6 about here)

\section{Solvency ratio}

KISA clusters show a higher solvency ratio in both periods compared with the figures for HTM, but the negative impact from the recession is more pronounced in KISA clusters. This means that despite the larger impact of the recession on solvency, KISA clusters are still more solvent than HTM clusters. This is evident for 16 and 15 HTM clusters showing negative solvency ratios in the two periods, respectively, whereas only 6 and 10 KISA are in the position on negative solvency ratios. Overall, there is also a weak association between liquidity growth and the solvency ratio across both sectors and both periods.

(Insert Table 7 about here)

\section{Findings from qualitative data}

Utilising conceptual content analysis we established the existence and frequency of concepts represented by words or phrases within the text/data. Our combined qualitative findings for the three dimensions provided further evidence by reiterating the importance of human capital (people) in driving organisations to be more resilient than others in business clusters 
during challenging times such as the recent global financial crises, as all 14 interviewees', across all the six sectors, confirmed this (see figure 2 that depicts this).

(Insert Figure 2 about here)

Figure 2 shows the various qualitative responses of the interviewees across the different industries operating in business clusters. The pharmaceutical sector respondent's mainly noted the following key aspects in their organisations in achieving resilience: qualities of being ambidextrous, the ability to multi-task and encouraging cognitive diversity within their employees and recognising and encouraging tenacity. Respondents from The ICT sector identified risk-taking culture, encouraging personal and group traits of resilience and investing in client base as imperative. At the same time, the computer and related activity sector identified learning and knowledge from previous experiences of dealing with adversity, the involvement of all levels of management and staff and being adaptive as the key concept of overcoming adversity by being resilient. Respondents from the medical, precision and optical instrument sector identified how value creation, concentration on short and long term challenges, encouraging integration for collaborative solution and encouragement of networking and its strength in social capital as key ingredient for being resilient. The aircraft and space craft sector identified capturing the experience of stress and depression in challenging times, recognizing accomplishment when overcoming adversity by being resilient and encouragement in innovation in times of adversity, as key concepts of being resilient. Respondents from the post and telecoms sector talked about being visionary to anticipate challenges, awareness of vulnerability, encouraging self-regulation to overcome disruption and being both adoptive and adaptive as the important areas to develop resilience. Last, but not the least, the R\&D sector identified how they invested in leadership that also included all levels of their workforce, awareness of their situation and vulnerability and selfregulation to prevent disruption as the key to overcoming adversity by being resilient.

In summary, factors within the human capital dimension, i.e. entrepreneurialism and employment growth were strong indicators of overcoming challenges and being resilient. As is evident from above, across the sectors, there were several examples of how these representative firms portrayed resilient behaviour during the financial crises because of their deep rooted entrepreneurial culture, which also translated to employment growth. The following table 8 shows the overall evidence (Prevalence of Resilience) across the sectors and dimensions. 
(Insert Table 8 about here)

\section{DISCUSSION AND CONCLUSION}

This paper attempts to measure the performance of business clusters from a quantitative and qualitative perspective. It is intended to fill a gap in the literature on business clusters, which is wide but largely qualitative and case study based. Our analysis shows various rankings of clusters according to detailed information about their human capital, economic dynamism and financial viability across the pre-recession and recession period.

The interpretation of our combined findings suggest that both indicators for the human capital dimension (i.e. entrepreneurship and employment growth) portray the more resilient clusters as compared with the less resilient clusters. Thus, the higher ranked clusters offer an environment which is conducive to weathering the recession through the continued establishment of dynamic capabilities (Teece, 1997) as represented by the knowledge based view of the firm. In doing so, it creates competitive advantage by allowing an atmosphere of entrepreneurship and employment growth as core capabilities. Our findings also confirm that human capital is an extremely important dimension to overcome surprising, uncertain, often adverse, and usually unstable situations and become resilient over time. Further, over a period of a time such firms with entrepreneurial capabilities of its people will create for the organisation a competitively advantageous position by being valuable, rare, inimitable and organizing in a unique manner (Barney and Wright, 1998; Hervás-Oliver \& Albors-Garrigós, 2007).

The interpretation of our findings for the two indicators under the second dimension (i.e. economic dynamics) is as follows. With regards to turnover growth, four important and extremely relevant aspects are highlighted by our results. The first aspect is that the minority of clusters has experienced a negative turnover growth impact during the recession. The second aspect is that turnover growth is highly correlated with entrepreneurialism. The third aspect is that turnover growth has resulted in job creation in many clusters (i.e. employment growth). The fourth aspect is that in times prior to the recession, a $1 \%$ increase in turnover in clusters is generating a bigger proportion of jobs. However, in the recession period, a $1 \%$ increase in turnover is matched by a $1 \%$ increase in extra jobs for both HTM and KISA clusters. This means that firms in clusters who are able to continue generation turnover growth can be considered resilient which feeds through to employment growth of similar magnitude. Overall, this illustrates relative prevalence of cluster resilience to the economic 
recession. In relation to the theoretical framework, our findings clearly suggest that the importance of people (i.e. human capital) within resilient organisations leads to positive economic dynamism which is then fed back into forming and developing a stronger human capital base that derives sustained competitive advantage in cluster network. This strongly suggests the prevalence of the resource based view (e.g. Hervás-Oliver \& Albors-Garrigós, 2007), albeit through human capital. However, there is a caveat to this aspect. The second indicator (i.e. profitability growth) shows us a much stronger negative impact of the recession on firms in clusters, thereby showing a reduced level of resilience as is evident from large movement in the ranking. This could be interpreted as most clusters not being able to sustain their competitive advantages through the VRIO lens.

The general interpretation of our findings for the last two indicators under the third dimension (i.e. financial viability) complement what we have found for the Economic dynamism and human capital dimensions, whereby the role and importance of human capital is paramount. We show that firms in KISA clusters seem to be more liquid than HTM cluster firms. This finding is similar for the solvency indicator. This highlights the differing levels of financial health with which firms in clusters to sustain their resilience, through its human capital. This potentially higher resilience is naturally linked to the human capital dimension through the fewer losses on the growth of turnover and profitability aspects. In summary, we find organisational resilience involves developing resilient capabilities such as those identified above (e.g. Kossek \& Perringino, 2016). These findings are consistent with the extant literature from psychology and management on harnessing resilience through its people in the face of growing business threats (Lengnick-Hall, Beck \& Lengnick-Hall, 2011; Carmeli \& Markman, 2011; Linnenluecke, 2015).

The key results of our analysis for the pre-recession period is that clusters from advanced countries (e.g. Germany, US and Sweden) seem to have perform better compared to less developed countries. However, in the recession period the better-performing clusters come from wider mix of countries, including for example Portugal and Ireland. Apart from entrepreneurialism and to some extent liquidity, the performance of clusters is quite volatile across the two periods, especially when viewed through the other indicators. This has different possible explanations, the most likely being that better performing clusters in times of economic expansion have different characteristics, dominated by greater quality of human capital, as suggested by our findings above, from those that weather more successfully periods of economic slowdown. This means resilient organisations, through their superior human capital overcame the financial crises as a major challenge. 
KISA clusters outperform those in HTM in terms of growth in employment and turnover. KISA clusters, though, appear to suffer the most due to the impact of the recession, enduring a stronger difference in growth rates across the two periods. Another important findings that is based on high correlations is that a high share of young firms boosts cluster turnover which in turn results in increased job creation, particularly in an economic boom, turnover growth also results in employment growth in clusters. This is testimony for the role and importance of human capital (resilience) in countering challenging times and situations.

Theoretically, we utilised the COR theory, and argue that even when external contingencies such as the GFC are not occurring, people within organisations are motivated and directed to lead their resources to obtain, retain and protect their resource-reservoirs. More specifically, we can interpret our overall results through the three core principles of COR. First, our findings clearly show that resource loss is disproportionately hurting organisations facing adversity such as the GFC as compared with a resource gain. Second, as can be seen from our first and second dimension, organisations must invest resources in order to protect against resource loss or to recover or gain resources. Our findings also suggest that greater resilient clusters are less vulnerable than clusters which were open to adversity along one or more dimensions of our framework, with the human capital dimension (people) being the dominant dimension overall. Third, our findings clearly suggest that resource gain increased when resource loss is high or chronic in the case of higher resilient clusters as resource loss asserted a key role for resource gain.

In conclusion, we offer a plausible theoretical explanation as follows. Our findings suggest through the lens of RBV that resources from an evaluation criteria (VRIO) and COR from a process of value creation of resources are complementary to each other. This is facilitated by the core concepts of caravan passageways and crossovers as the micro dimensions that through our findings highlight the process of sustained competitive advantage at individual, firm and cluster level. As depicted in our theoretical model, caravan passageways were the tunnel through which the resources travelled via process creating, aggregating and sustaining one another. Whereas, crossovers were the bridge via which the resources overcame adversity and became resilient.

We argue that our findings are generalizable to other clusters, outside of our chosen clusters, as well as non-cluster regions of a country. The reason for this is that the notion of resilience in clusters is certainly of utmost importance due to the fast-paced and harsh competition that organisations compete and collaborate with each other. The same lessons 
surrounding investments in human capital, economic dynamism and financial viability are valid in non-cluster regions and other less-technology/knowledge industries.

The managerial implications of our study are that beyond the firm/cluster dimension of our analysis, we can only offer general trends of human capital investment in terms of crisis, such as the global financial crisis. The uncovering of human capital as the leading indicator for organisations can help managers focus their efforts in driving and developing resilience as opposed to the dimensions of economic dynamism and financial viability. This fact which has not been shown for business clusters is relevant for company executives in their quest to enhance employee resilience in their respective organisations.

\section{References}

Acemoglu, D., Ozdaglar, A., \& Tahbaz-Salehi, A. (2013). The Network Origins of Large Economic Downturns, Working paper No. 19230. National Bureau of Economic Research.

Acemoglu, D., Ozdaglar, A., \& Tahbaz-Salehi, A. (2015). Systemic risk and stability in financial networks. The American Economic Review, 105(2), 564-608.

Ambulkar, S., Blackhurst, J., \& Grawe, S. (2015). Firm's resilience to supply chain disruptions: Scale development and empirical examination. Journal of Operations Management, 33, 111-122.

Asheim B.T. and Moodysson, J. (2008), The Öresund region: A dynamic region in Europe due to inter-regional collaboration?, Working Papers On Line, Autonomous University of Barcelona.

Athreye, S. (2004), Agglomeration and Growth: A Study of the Cambridge Hi-Tech Cluster, in Bresnahan, T. and A. Gambardella (eds.), Building High-Tech Clusters: Silicon Valley and Beyond, Cambridge University Press, New York.

Audretsch, D. B. and M. Feldman, (1996), Innovative Clusters and the Industry Life Cycle, Review of Industrial Organisation, 11, 253-273.

Bakker, A. B., \& Schaufeli, W. B. (2000). Burnout contagion processes among teachers. Journal of Applied Social Psychology, 30(11), 2289-2308.

Bandura, A. (1995). Self-efficacy in Changing Societies. Cambridge University Press.

Barinaga, E. and L. Ramfelt (2004), Kista: The Two Sides of the Network Society Networks and Communication Studies, 18 (3/4), 225-244.

Barney, J. B. (1991). Firm resources and sustained competitive advantage. Journal of Management, 17, 99-120.

Barney, J.B., \& Wright, P.M. (1998). On becoming a strategic partner: The role of human resources in gaining competitive advantage. Human Resource Management, 37, 3146.

Basant, R. (2006), Bangalore Cluster: Evolution, Growth and Challenges, IIMA Working Papers WP2006-05-02, Indian Institute of Management, Ahmadabad.

Bathelt, H., \& Boggs, J. S. (2003). Toward a reconceptualization of regional development paths: Is Leipzig's media cluster a continuation of or a rupture with the past? Economic Geography, 79(3), 265-293.

Baptista, R., \& Swann, P. (1998). Do firms in clusters innovate more? Research Policy, 27(5), 525-540. 
Becattini, G. (1990), The Marshallian Industrial District as a Socio-economic Notion, in F. Pyke, G. Becattini, and W. Sengenberger (eds.), Industrial Districts and Inter-firm Cooperation in Italy, International Institute for Labour Studies, Geneva.

Belussi, F., A. Sammarra and R. Sedita (2008), Industrial Districts Evolutionary Trajectories: Localized Learning Diversity and External Growth, paper presented at the DRUID conference on "Entrepreneurship and Innovation: Organisation, Institutions, Systems and Regions", Copenhagen, June 2008.

Benight, C. C. (2004). Collective efficacy following a series of natural disasters. Anxiety, Stress \& Coping, 17(4), 401-420.

Bock, A. J., Opsahl, T., George, G., \& Gann, D. M. (2012). The effects of culture and structure on strategic flexibility during business model innovation. Journal of Management Studies, 49(2), 279-305.

Botelho, A.J., G. Stefaunto and F. Veloso (2005), The Brazilian Software Industry, in A. Arora and A. Gambardella, From Underdogs to Tigers: The Rise and Growth of the Software Industry in Brazil, China, India, Ireland, and Israel, Oxford University Press, Oxford.

Bonanno, G. A., Romero, S. A., \& Klein, S. I. (2015). The temporal elements of psychological resilience: An integrative framework for the study of individuals, families, and communities. Psychological Inquiry, 26(2), 139-169.

Braunstein-Bercovitz, H., Frish-Burstein, S., \& Benjamin, B. A. (2012). The role of personal resources in work-family conflict: Implications for young mothers' wellbeing. Journal of Vocational Behavior, 80(2), 317-325.

Braczyk, H. J., P. Cooke and M. Heidenreich (1998), Regional Innovation Systems, UCL Press, London.

Bramwell, A., J. Nelles and D. Wolfe (2008), Knowledge, Innovation and Institutions: Global and Local Dimensions of the ICT Cluster in Waterloo, Canada, Regional Studies, 42, $1-16$.

Bresnahan, T., \& Gambardella, A. (Eds.). (2004). Building high-tech clusters: Silicon Valley and beyond. Cambridge University Press.

Budd, J.W., J. Konings and M.J. Slaughter, (2005), Wages and International Rent Sharing in Multinational Firms, Review of Economics and Statistics.

Carley, K. (1990). Content analysis. In R.E. Asher (Ed.), The Encyclopedia of Language and Linguistics. Edinburgh: Pergamon Press.

Carmeli, A., \& Gittell, J. H. (2009). High-quality relationships, psychological safety, and learning from failures in work organisations. Journal of Organisational Behavior, 30(6), 709-729.

Carmeli, A. and Markman, G.D., 2011. Capture, governance, and resilience: strategy implications from the history of Rome. Strategic Management Journal, 32(3), 322341.

Carmeli, A., Friedman, Y., \& Tishler, A. (2013). Cultivating a resilient top management team: The importance of relational connections and strategic decision comprehensiveness. Safety Science, 51(1), 148-159.

Carmeli, A., Yitzhak-Halevy, M. and Weisberg, J., 2009. The relationship between emotional intelligence and psychological wellbeing. Journal of Managerial Psychology, 24(1), 66-78.

Chaminade, C. (1999), Innovation Processes and Knowledge Flows in the Information and Communications Technologies (ICT) cluster in Spain, in OECD, Boosting

Innovation: The Cluster Approach, OECD Publishing, Paris.

Chen, G., \& Bliese, P. D. (2002). The role of different levels of leadership in predicting self- 
and collective efficacy: evidence for discontinuity. Journal of Applied Psychology, 87(3), 549.

Chen, S., Westman, M., \& Hobfoll, S. E. (2015). The commerce and crossover of resources: Resource conservation in the service of resilience. Stress and Health, 31(2), 95-105.

Chen, Y. (2008), Why do Multinational Corporations Locate their Advanced R\&D Centres in Beijing, Journal of Development Studies, n. 44 (5), 622-644.

Cooke, P. (2001), Regional Innovation systems, Clusters, and the Knowledge Economy, Industrial and Corporate Change, 10, 945-974.

Corolleur, F., V. Mangematin and A. Torre (2003), French Biotech Start Ups and Biotech Clusters in France: The Importance of Geographic Proximity, in G. Fuchs and B. Luib (eds.), Biotechnology in Comparative Perspective: Growth and Regional Concentration, Routledge, London.

Coutu, D. L. (2002). How resilience works. Harvard Business Review, 80(5), 46-56.

Dahl, M.S., C. Pedersen and B. Dalum (2003), Entry by Spinoff in a High-tech Cluster, DRUID Working Papers 03-11, Copenhagen Business School.

De Fonteney, B. and N. Carmel (2002), Israel's Silicon Wadi: The Forces Behind Cluster Formation, Berkley Business Review, 1-36.

Delgado M., M.E. Porter, and S. Stern, 2010, Clusters and Entrepreneurship, Journal of Economic Geography, 10(4), 495-518.

Delgado, M., M.E. Porter, and S. Stern, 2014, Clusters, Convergence, and Economic Performance, Research Policy, 43 (10), 1785-1799.

Delgado, M., Porter, M. E., \& Stern, S. (2014). Clusters, convergence, and economic performance. Research Policy, 43(10), 1785-1799.

Delgado, M., Porter, M.E., Stern, S. (2015), Clusters and the Great Recession. Paper presented at the 2015 DRUID Conference. Rome.

Diniz, C.C. and M. Razavi (1995), High Technology and New Industrial Areas in Brazil: the Development of Sao Jose dos Campos and Campinas Cities, CEDEPLAR, Texto para Discussão no. 94, UFMG - Regional Planning and Development Centre, Belo Horizonte.

Driffield, N., Pereira, V. and Temouri, Y. (2017). Does Offshore Outsourcing impact home employment? Evidence from service multinationals, Journal of Business Research, forthcoming.

Elbert, A., F. Muller and D.J. Persch, (2009), ICT cluster, Technical University of Darmstadt, available at: http://www.hessen-it.de/mm/IKT-StudieKurzfassung_V4_eng tcm16-53755.pdf

Ennis, N. E., Hobfoll, S. E., \& Schröder, K. E. (2000). Money Doesn't Talk, It Swears: How Economic Stress and Resistance Resources Impact Inner-City Women's Depressive Mood. American Journal of Community Psychology, 28(2), 149-173.

Feldman, M. P., \& Audretsch, D. B. (1999). Innovation in cities: Science-based diversity, specialization and localized competition. European Economic Review, 43(2), 409429.

Ferris, P. A., Sinclair, C., \& Kline, T. J. (2005). It takes two to tango: Personal and organisational resilience as predictors of strain and cardiovascular disease risk in a work sample. Journal of Occupational Health Psychology, 10(3), 225.

Fredrickson, B. L. 2001. The role of positive emotions in positive psychology: The broadenand-build theory of positive emotions. American Psychologist, 56(3): 218-226.

Gassler, H. and J. Frohlich (1998), The Regional Variation of New Technology-based Firms in Austria, European Regional Science Association Conference Paper. 
Giblin, M. and L. Martinez-Solano (2003), The Atlantic Technology Corridor: Problems and Prospects of Cluster Formation in Ireland, paper presented at the Conference on Innovation in Europe, Roskilde, Denmark, May, 2003.

Giblin, M., R. Green, R. and M. Moroney (2002), Atlantic Technology Corridor: Dynamics of Cluster Development in Ireland, Irish Academy of Management Conference, Waterford.

Giuliani E. (2005), Cluster Absorptive Capacity: Why do Some Clusters Forge Ahead and Others Lag Behind, European Urban and Regional Studies, 12 (3), 269-288.

Glaeser, E. L., \& Kerr, W. R. (2009). Local industrial conditions and entrepreneurship: how much of the spatial distribution can we explain? Journal of Economics \& Management Strategy, 18(3), 623-663.

Goldstein, A. (2002), The Political Economy of High-Tech Industries in Developing Countries: Aerospace in Brazil, Indonesia and South Africa, Cambridge Journal of Economics, Oxford University Press, 26(4), 521-538.

Halbesleben, J. R., Neveu, J. P., Paustian-Underdahl, S. C., \& Westman, M. (2014). Getting to the "COR" understanding the role of resources in conservation of resources theory. Journal of Management, 40(5), 1334-1364.

Hamel, G. and Prahalad, CK (1994), Competing for the Future, Harvard Business School Press, Boston.

Hamel, G., \& Valikangas, L. (2003). The quest for resilience. Harvard Business Review, 81(9), 52-65.

Hammer, L. B., Allen, E., \& Grigsby, T. D. (1997). Work-family conflict in dual-earner couples: Within-individual and crossover effects of work and family. Journal of Vocational Behavior, 50(2), 185-203.

Harper, D., R. White, M. van Leeuwen, M. Holi, J. Lawton, Coffman, C., R. Franklin and E. Hugo (2007), Looking Inwards, Reaching Outwards: The Cambridge Cluster Report, Library House.

Häussler, C. and H. M. Zademach (2006), Cluster Performance reconsidered: Structure, Linkages and Paths in the German Biotechnology Industry, 1996-2003, Discussion Papers 188, SFB/TR 15 Governance and the Efficiency of Economic Systems, Free University of Berlin.

Helper, S., MacDuffie, J. P., \& Sabel, C. (2000). Pragmatic collaborations: advancing knowledge while controlling opportunism. Industrial and Corporate Change, 9(3), 443-488.

Helpman, E., Melitz, M.J, and Yeaple, S.R. (2004), Export Versus FDI with Heterogeneous Firms, American Economic Review, 94, 300-316.

Hervás-Oliver, J. L. \& Albors-Garrigós, J. (2007) Do clusters capabilities matter? An empirical application of the resource-based view in clusters, Entrepreneurship and Regional Development, 19(2), 113-136.

Hitt, M. A., Keats, B. W., \& DeMarie, S. M. (1998). Navigating in the new competitive landscape: Building strategic flexibility and competitive advantage in the $21 \mathrm{st}$ century. Academy of Management Executive, 12(4), 22-42.

Hobfoll, S. E. (2002). Social and psychological resources and adaptation. Review of General Psychology, 6(4), 307.

Hobfoll, S. E. (2011). Conservation of resource caravans and engaged settings. Journal of Occupational and Organisational Psychology, 84(1), 116-122.

Hobfoll, S. E. (2012). Conservation of resources and disaster in cultural context: The caravans and passageways for resources. Psychiatry: Interpersonal \& Biological Processes, 75(3), 227-232.

Hobfoll, S. E., Stevens, N. R., \& Zalta, A. K. (2015). Expanding the science of resilience: 
Conserving resources in the aid of adaptation. Psychological inquiry, 26(2), 174-180.

Hobfoll, S. E., Hall, B. J., Canetti-Nisim, D., Galea, S., Johnson, R. J., \& Palmieri, P. A.

(2007). Refining our understanding of traumatic growth in the face of terrorism:

Moving from meaning cognitions to doing what is meaningful. Applied Psychology:

An International Review, 56(3), 345-366.

Home, J. F., \& Orr, J. E. (1997). Assessing behaviors that create resilient organisations. Employment Relations Today, 24(4), 29-39.

Honkamakila, H. (2009), Introducing New Regions: Oulu Region, Finland, in OECD Reviews of Higher Education in Regional and City development, Roundtable for Regions.

Horne III, J. F. (1997). The coming age of organisational resilience. In Business forum (22(2/3), 24). California State University, Los Angeles, School of Business and Economics.

Hulsink, W., H. Bouwman, and T. Elfring (2007), Silicon Valley in the Polder? Entrepreneurial Dynamics, Virtuous Clusters and Vicious Firms in the Netherlands and Flanders, Research Paper ERS-2007-048-ORG, Erasmus Research Institute of Management (ERIM), Rotterdam.

Jansen, J. J. P., George, G., van Den Bosch, F. A. J., and Volberda, H. W. (2008). Senior team attributes and organisational ambidexterity: The moderating role of transformational leadership. Journal of Management Studies, 45(5), 982-1007.

Jeong, J.H. and J.M Lee (2006), Identifying Industrial Clusters in Korea, Korea Institute for Industrial Economics and Trade (KIET), Seoul.

Jung, D. I., \& Sosik, J. J. (2003). Group potency and collective efficacy examining their predictive validity, level of analysis, and effects of performance feedback on future group performance. Group \& Organisation Management, 28(3), 366-391.

Junni, P., Sarala, R. M., Taras, V., \& Tarba, S. Y. (2013). Organisational ambidexterity and performance: A meta-analysis. The Academy of Management Perspectives, 27(4), 299-312.

Karaev, A., Lenny Koh, S. C., \& Szamosi, L. T. (2007). The cluster approach and SME competitiveness: a review. Journal of Manufacturing Technology Management, 18(7), 818-835.

Klein, R. J. T., Nicholls, R. J., \& Thomalla, F. (2003). Resilience to natural hazards: How useful is this concept? Global Environmental Change Part B: Environmental Hazards, 5(1), 35-45.

Kodama, T. (2004), Cluster Promoting Initiatives in Japan, presented at the OECD-EU Conference on Innovation and Regional Development, November 2004, Florence.

Konings, J. and A. Murphy (2006), Do Multinational Enterprises Relocate Employment to Low-Wage Regions? Evidence from European Multinationals, Review of World Economics, 142(1), 1-20.

Kossek, E. E., \& Perrigino, M. B. (2016). Resilience: A review using a grounded integrated occupational approach. Academy of Management Annals, 10 (1), 729-797.

Kranton, R. E., \& Minehart, D. F. (2000). Networks versus vertical integration. The Rand Journal of Economics, 570-601.

Krugman, P. (1991), Geography and Trade. MIT Press, Cambridge, MA

Lambert, B. H. (2000), Building Innovative Communities: Lessons from Japan's Science City Projects, EIJS Working Paper Series 107,The European Institute of Japanese Studies.

Lee, J. (2003), Development Strategies of Daedeok Valley: To build it as the R\&D Hub of Northeast Asia, http://www.wtanet.org/english/referenceroom/dataBDList.mf?tableName=Eforum

Lee, R., Clark, G. L., Pollard, J. \& Leyshon, A. (2009) The remit of financial geography- 
before and after the crisis, Journal of Economic Geography, 9(5), 723-747.

Lengnick-Hall, C. A., Beck, T. E., \& Lengnick-Hall, M. L. (2011). Developing a capacity for organisational resilience through strategic human resource management. Human Resource Management Review, 21(3), 243-255.

Leonard, D. (1998). Wellsprings of knowledge: Building and sustaining the sources of innovation. Boston: Harvard Business School Press.

Linnenluecke, M. K. (2015). Resilience in business and management research: A review of influential publications and a research agenda. International Journal of Management Reviews.

Liu, Y., Wang, Z., \& Lü, W. (2013). Resilience and affect balance as mediators between trait emotional intelligence and life satisfaction. Personality and Individual Differences, 54(7), 850-855.

Lorenzen, M. and M. Volker (2002), Global Strategy and the Acquisition of Local Knowledge: How MNCs Enter Regional Knowledge Clusters, DRUID Working Papers 02-08, Copenhagen Business School.

Luthans, F. (2002). The need for and meaning of positive organisational behavior. Journal of Organisational Behavior, 23(6), 695-706.

Malmberg, A., \& Power, D. (2005). (How) do (firms in) clusters create knowledge? Industry and innovation, 12(4), 409-431.

Malik, A., Pereira, V. \& Budhwar, P. (2017) Value creation and capture through human resource management practices: Gazing through the business model lens, Organisational Dynamics, forthcoming.

Mallak, L. A. (1998a). Measuring resilience in health care provider organisations. Health Manpower Management, 24(4), 148-152.

Mallak, L. (1998b). Putting organisational resilience to work. Industrial Management, 40(6), 8-13.

Manyena, S. B. (2006). The concept of resilience revisited. Disasters, 30(4), 434-450.

Mets, T. (2005), Innovation Paths of Estonian Biotechnology, Tallinn School of Economics and Business Administration Working Paper n 131, Tallinn.

Morgeson, F. P., \& Hofmann, D. A. (1999). The structure and function of collective constructs: Implications for multilevel research and theory development. Academy of Management Review, 24(2), 249-265.

Munn-Venn, T. and R. Voyer (2004), Clusters of Opportunity, Clusters of Risk, The Conference Board of Canada, Ottawa.

Mytelka, L.K. (2004), Clustering, Long-distance Partnerships and the SME: a Study of the French Biotechnology Sector, International Journal of Technology Management, 27(8), 791-808.

Nadvi K. and H. Schmitz (eds.) (1999), Industrial Clusters in Developing Countries, World Development, 27 (9), 1503-1734.

Niosi, J. and M. Zhegu, M. (2005), Aerospace Clusters: Local or Global Knowledge Spillovers?, Industry and Innovation.

Norgall, T. (2010), ICT Solutions for Enhanced Mobility of Elderly People - State of the Art Examples from the Nuremberg Metropolitan Region, Fraunhofer Institute Integrated Circuits, Brussels.

OECD (1999), Boosting Innovation: The cluster Approach, OECD Publishing, Paris.

OECD (2001), Innovative Clusters: Drivers of National Innovation Systems, OECD Publishing, Paris.

OECD (2004), OECD Territorial Reviews: Montreal, Canada, OECD Publishing, Paris.

OECD (2006), OECD Territorial Reviews: Stockholm, OECD Publishing, Paris. 
OECD (2007), Competitive Regional Clusters: National Policy Approaches, OECD Publishing, Paris.

OECD (2007), Staying Competitive in the Global Economy: Moving up the Value Chain, OECD Publishing, Paris

OECD (2009), Clusters, Innovation and Entrepreneurship, OECD Publishing, Paris.

OECD (2010), SMEs, Entrepreneurship and Innovation, OECD Publishing, Paris.

Olcott, G., \& Oliver, N. (2014). Social Capital, Sensemaking, and Recovery. California Management Review, 56(2), 5-22.

Ollier-Malaterre, A. (2010). Contributions of work-life and resilience initiatives to the individual/organisation relationship. Human Relations, 63(1), 41-62.

Onsager, K., A. Isaksen, M. Fraas, \& Johnstad, T. (2007), Technology Cities in Norway: Innovation in Glocal Networks, European Planning Studies, 15(4), 549-566 Oxfordshire bioscience cluster paper 2005, Oxfordshire bioscience network.

Patton, D. and M. Kenney (2009), The University Research-Centric District in the USA, forthcoming in Handbook of Industrial Districts, Edward Elgar Publishing.

Penrose, E. T. (1959). The Theory of the Growth of the Firm. New York: John Wiley

Pereira, V. \& Malik, A. (2015), Human capital in the Indian IT/BPO industry, Palgrave Macmillan, United Kingdom.

Piore M. and C. Sabel (1984), The Second Industrial Divide, Basic Books, New York.

Porter, M. E. (1990), The Competitive Advantage of Nations, Free Press, New York.

Porter, M. E. (1998). Clusters and the new economics of competition, Harvard Business Review, 76(6), 77-90.

Porter, M.E. (1996), What is Strategy, Harvard Business Review.

Porter, M.E. (1998), Clusters and the New Economics of Competition, Harvard Business Review, 76(6)

Porter, M.E. (2000), Location, Competition, and Economic Development: Local Clusters in a Global Economy, Economic Development Quarterly, 14, 15-34.

Porter, M.E. and J. Ramirez-Vallejo (2011), The Minnesota Medical Devices Cluster, Harvard Business School Publishing Corporation, Boston.

Pratt, L. and J. Vieto (1999), Eco-Efficiency in a High-Tech Cluster: A meta Analysis of the Evolving High-tech Electronics Cluster Headed by Intel in Costa Rica available at http://www.incae.edu/ES/clacds/publicaciones/pdf/cen703final.pdf

Procyshyn, T.L. (2004), Saskatoon's Agricultural Biotechnology Cluster and the Canadian Light Source: An Assessment of the Potential for Cluster Extension, available at http://www.usask.ca/politic/phillips/pdfs/Procyshyn\%20-\%20Thesis.pdf.

Ribeiro, S. P., Menghinello, S., \& De Backer, K. (2010). The OECD ORBIS database: Responding to the need for firm-level micro-data in the OECD. OECD Statistics Working Papers, 2010(1), 1.

Rocha, H. O. (2004). Entrepreneurship and development: The role of clusters. Small Business Economics, 23(5), 363-400.

Saxenian, A. (1994), Regional Advantage: Culture and Competition in Silicon Valley and Route 128, Harvard University Press, Boston.

Shepherd, D. A., Wiklund, J., \& Haynie, J. M. (2009). Moving forward: Balancing the financial and emotional costs of business failure. Journal of Business Venturing, 24(2), 134-148.

Shin, J., Taylor, M.S. and Seo, M.G. (2012). Resources for change: The relationships of organisational inducements and psychological resilience to employees' attitudes and behaviors toward organisational change. Academy of Management Journal, 55(3), 727-748.

Solomon, M. (1993). Content analysis: a potent tool in the searcher's arsenal. Database, 16(2), 
62-67.

Stajkovic, A. D., Lee, D., \& Nyberg, A. J. (2009). Collective efficacy, group potency, and group performance: Meta-analyses of their relationships, and test of a mediation model. Journal of Applied Psychology, 94(3), 814-828.

Stephens, J. P., Heaphy, E. D., Carmeli, A., Spreitzer, G. M., \& Dutton, J. E. (2013). Relationship quality and virtuousness: Emotional carrying capacity as a source of individual and team resilience. The Journal of Applied Behavioral Science, 49(1), 13-41.

Stoerring, D. and J.L. Christensen (2008), Clusterpreneurs - Promoting High-Tech Clusters in Low-Tech Regions, Working Paper Series No. 12, 2008, Aalborg University, Department of Business Studies.

Sutcliffe, K.M., \& Vogus, T.J. (2003), Organizing for resilience. In Cameron, K.S., Dutton, J.E. and Quinn, R.E. (eds), Positive Organisational Scholarship: Foundations of A New Discipline. San Francisco, CA: Berrett-Koehler.

Teece, D. J., Pisano, G. \& Shuen, A. (1997), Dynamic capabilities and strategic management, Strategic Management Journal, 18, 7, 509-33.

Teigland, R., D. Hallencreutz and P. Lundequist (2005), Uppsala BIO - the Life Science Initiative Experiences of and Reflections on Starting a Regional Competitiveness Initiative, CIND Research Paper 2005:3, Centre for Research on Innovation and Industrial Dynamics, Uppsala University.

Teigland, R.., G. Lindqvist, A. Malmberg and A. Waxwell (2004), Investigating the Uppsala Biotech Cluster, CIND Research Paper 2004:1, Centre for Research on Innovation and Industrial Dynamics, Uppsala University.

Temouri, Y., N. Driffield and D. Higón (2008), Analysis of Productivity Differences among Foreign and Domestic Firms: Evidence from Germany, Review of World Economics, 144(1), 32-54.

Ter Wal, A. (2010), Cluster Emergence and Network Evolution: A Longitudinal Analysis of the Inventor Network in Sophia-Antipolis, Regional Studies, 45.

Teräs, J. (2008), Regional Science-based Clusters: A Case Study of three European Concentrations, Thesis from the Faculty of Technology of the University of Oulu, Finland.

Van den Berg, L., Braun, E., \& Van der Meer, J. (1997). The organising capacity of metropolitan region. Environment and Planning C: Government and Policy, 15(3), 253-272.

Weber, R. P. (1990). Basic content analysis, second edition. Newbury Park, CA: Sage Publications.

Wernerfelt, B. (1984). A resource-based view of the firm. Strategic Management Journal, 5, $171-80$.

Westman, M. (2001). Stress and strain crossover. Human Relations, 54, 557-591.Westman, M. (2001). Stress and strain crossover. Human Relations, 54(6), 717-751.

Westman, M. (2013). Crossover of positive states and experiences. Stress Health, 29, $263-$ 265.

Westman, M., \& Etzion, D. (1995). Crossover of stress, strain and resources from one spouse to another. Journal of Organisational Behavior, 16(2), 169-181.

Westman, M., Etzion, D., \& Chen, S. (2009). The crossover of exhaustion and vigor between international business travelers and their spouses. Journal of Managerial Psychology, 24, 269-284.

Westman, M., Etzion, D., \& Gattenio, E. (2008). International business travels and the workfamily interface: A longitudinal study. Journal of Occupational and Organisational Psychology, 81(3), 459-480. 
Westman, M., Etzion, D., \& Horovitz, S. (2004). The toll of unemployment does not stop with the unemployed. Human Relations, 57(7), 823-844.

Westman, M., Shadach, E., \& Keinan, G. (2013). The crossover of positive and negative emotions: The moderating effect of empathy. International Journal of Stress Management, 20, 116-133.

Williams, T. A., \& Shepherd, D. A. (2016). Building resilience or providing sustenance: Different paths of emergent ventures in the aftermath of the Haiti earthquake. Academy of Management Journal, 59(6), 2069-2102.

Winden van, W. and P. Woets (2003), Local Strategic Networks and Policies in European ICT Clusters: The cases of Amsterdam, Bari, Dublin and Oulu, paper prepared for the 15th Annual Conference of the European Association for Evolutionary Political Economy, Maastricht, the Netherlands, 7-10 November 2003.

Wolfe, D. (2002), Knowledge, Learning and Social Capital in Ontario's ICT Clusters, Paper prepared for the Annual Meeting of the Canadian Political Science Association, 29-31 May 2002, Toronto.

Wonglimpiyarat, J. (2006), The Boston Route 128 Model of High-Tech Industry Development, International Journal of Innovation Management, 10(1), 47-63.

Wrobel, M. (2013), One for all and all for one: Cluster, employment, and the global economic crisis. Evidence from the German mechanical engineering industry, Papers in Regional Science, 92(4).

Youssef, C. M., \& Luthans, F. (2007). Positive organisational behavior in the workplace: The impact of hope, optimism, and resilience. Journal of Management, 33(5), 774-800.

Zautra, A. J., Hall, J. S., \& Murray, K. E. (2010). Resilience: A new definition of health for people and communities. In W. Reich, \& A. Zautra (Eds.), Handbook of adult resilience (3-35). New York: Guilford. 
Table 1: List of Respondents

\begin{tabular}{|l|l|c|}
\hline \multicolumn{1}{|c|}{$\begin{array}{c}\text { Sector/Trends } \\
\text { (codes in brackets below) }\end{array}$} & Number of interviews \\
\hline $\begin{array}{l}\text { High-tech } \\
\text { manufacturing }\end{array}$ & $\begin{array}{l}\text { Aircraft and } \\
\text { spacecraft (AS) }\end{array}$ & 2 \\
\cline { 2 - 3 } & $\begin{array}{l}\text { Pharmaceuticals } \\
\text { (P) }\end{array}$ & 2 \\
\cline { 2 - 3 } & $\begin{array}{l}\text { Medical, precision, } \\
\text { and optical } \\
\text { instruments } \\
\text { (MPOI) }\end{array}$ & 2 \\
\hline \multirow{2}{*}{$\begin{array}{l}\text { Knowledge- } \\
\text { services }\end{array}$} & $\begin{array}{l}\text { Post and } \\
\text { telecommunication } \\
\text { s (PT) }\end{array}$ & 2 \\
\cline { 2 - 3 } & $\begin{array}{l}\text { ICT, computer and } \\
\text { related activities } \\
\text { (ICT) }\end{array}$ & 2 \\
\cline { 2 - 3 } & $\begin{array}{l}\text { Research and } \\
\text { development (RD) }\end{array}$ & 2 \\
\hline
\end{tabular}

Table 2 Ranking of business clusters by proportion of young firms (aged below 5 years)

\begin{tabular}{|c|c|c|c|c|c|c|c|c|c|c|c|}
\hline \multirow[b]{2}{*}{ Name of cluster } & \multirow[b]{2}{*}{ Country } & \multicolumn{2}{|c|}{ Pre-recession } & \multicolumn{2}{|c|}{ Recession } & \multirow[b]{2}{*}{ Name of cluster } & \multirow[b]{2}{*}{ Country } & \multicolumn{2}{|c|}{ Pre-recession } & \multicolumn{2}{|c|}{ Recession } \\
\hline & & Rank & $\begin{array}{c}\% \\
\text { young } \\
\text { firms }\end{array}$ & Rank & $\begin{array}{c}\% \\
\text { young } \\
\text { firms }\end{array}$ & & & Rank & $\begin{array}{c}\% \\
\text { young } \\
\text { firms }\end{array}$ & Rank & $\begin{array}{c}\% \\
\text { young } \\
\text { firms }\end{array}$ \\
\hline Tartu & Estonia & 1 & 27.3 & 2 & 34.1 & Pervasive Computing Cluster & Denmark & 1 & 31.3 & 1 & 41.1 \\
\hline
\end{tabular}




\begin{tabular}{|c|c|c|c|c|c|c|c|c|c|c|c|}
\hline Mechatronics Cluster & Denmark & 2 & 27.3 & 4 & 27.3 & Atlantic Technology Corridor & Ireland & 2 & 30 & 2 & 40.3 \\
\hline Instrumentation Trondheim & Norway & 3 & 26.7 & 8 & 21.6 & Information processing cluster & Spain & 3 & 30 & 12 & 24.1 \\
\hline Heidelberg & Germany & 4 & 26.4 & 19 & 18.6 & Bari ICT Cluster & Italy & 4 & 29.1 & 8 & 28.2 \\
\hline Oxfordshire bioscience cluster & UK & 5 & 26.4 & 3 & 30 & Beijing & China & 5 & 27.6 & 24 & 19.2 \\
\hline Optical Tech Cluster & Germany & 6 & 24.7 & 11 & 20.8 & Oxfordshire R\&D Cluster & UK & 6 & 27.2 & 4 & 31.3 \\
\hline Cambridge Fen & UK & 7 & 23.3 & 5 & 26.1 & ICT Cluster Dublin & Ireland & 7 & 26.9 & 3 & 34.9 \\
\hline Life Science cluster (LISA) & Austria & 8 & 22.3 & 14 & 19.8 & Twente ICT cluster & Netherlands & 8 & 23.6 & 10 & 26.7 \\
\hline Madison research district & USA & 9 & 20.6 & 7 & 24.6 & $\begin{array}{l}\text { Telecommunications in North } \\
\text { Jutland }\end{array}$ & Denmark & 9 & 23 & 5 & 30.4 \\
\hline Toulouse aerospace cluster & France & 10 & 19.1 & 30 & 13.1 & Daedoek Science Town & Korea & 10 & 22.2 & 19 & 20.4 \\
\hline Gothenburg Bio cluster & Sweden & 31 & 12.9 & 24 & 15.8 & Ottawa ICT cluster & Canada & 31 & 9.9 & 34 & 7.7 \\
\hline Montreal Biotech cluster & Canada & 32 & 11.7 & 34 & 7.9 & Cornell research district & USA & 32 & 9.2 & 31 & 11.5 \\
\hline Micro- and Nanotechnology Horten & Norway & 33 & 9.1 & 36 & 4.5 & Yokosuka Research Park & Japan & 33 & 7.7 & 32 & 9.6 \\
\hline Toyama Medical-Bio Cluster & Japan & 34 & 7.7 & 37 & 3.8 & Macquarie Park, Sydney & Australia & 34 & 6.4 & 35 & 6.4 \\
\hline Fiberoptic Valley & Sweden & 35 & 7.3 & 33 & 8.9 & Health care/Medical research & USA & 35 & 5.3 & 33 & 8.8 \\
\hline Leuven & Belgium & 36 & 6.8 & 23 & 15.9 & Sao Paulo & Brazil & 36 & 3.6 & 37 & 2.8 \\
\hline Ishikawa High-tech Sensing Cluster & Japan & 37 & 6.3 & 35 & 5.5 & Silicon Valley of Mexico & Mexico & 37 & 2.5 & 38 & 2.5 \\
\hline Saskatoon (Ag Biotech) & Canada & 38 & 5.5 & 39 & 2.2 & Bangalore & India & 38 & 2.1 & 36 & 3.6 \\
\hline Beijing & China & 39 & 5.1 & 38 & 2.4 & Brazilian Silicon Valley & Brazil & 39 & 0.4 & 39 & 0.3 \\
\hline Sao Paulo & Brazil & 40 & 1.6 & 40 & 1.6 & Silicon Wadi & Israel & 40 & 0 & 40 & 0 \\
\hline
\end{tabular}

Source: Authors elaboration based on ORBIS database available from Bureau van Dijk.

Table 3 Ranking of business clusters by employment growth

\begin{tabular}{|c|c|c|c|c|c|c|c|c|c|c|c|}
\hline \multirow[b]{2}{*}{ Name of cluster } & \multirow[b]{2}{*}{ Country } & \multicolumn{2}{|c|}{ Pre-recession } & \multicolumn{2}{|c|}{ Recession } & \multirow[b]{2}{*}{ Name of cluster } & \multirow[b]{2}{*}{ Country } & \multicolumn{2}{|c|}{ Pre-recession } & \multicolumn{2}{|c|}{ Recession } \\
\hline & & Rank & $\begin{array}{c}\% \\
\text { Growth }\end{array}$ & Rank & $\begin{array}{c}\% \\
\text { Growth }\end{array}$ & & & Rank & $\begin{array}{c}\% \\
\text { Growth }\end{array}$ & Rank & $\begin{array}{c}\% \\
\text { Growth }\end{array}$ \\
\hline Oslo Cancer Cluster & Norway & 1 & 71.3 & 3 & 35.6 & Cornell research district & USA & 1 & 83.3 & 19 & 15.6 \\
\hline Madison research district & USA & 2 & 62.5 & 15 & 10.5 & Health care/Medical research & USA & 2 & 70.1 & 21 & 14.1 \\
\hline Leuven & Belgium & 3 & 46.9 & 22 & 8.6 & Silicon Valley & USA & 3 & 59.3 & 18 & 15.8 \\
\hline Boston (Route 128) & USA & 4 & 46.1 & 9 & 14 & Louvain Technology Corridor & Belgium & 4 & 56.6 & 7 & 29.3 \\
\hline
\end{tabular}




\begin{tabular}{|c|c|c|c|c|c|c|c|c|c|c|c|}
\hline Life Science cluster (LISA) & Austria & 5 & 40 & 1 & 48.2 & Oslo & Norway & 5 & 55.6 & 11 & 21.6 \\
\hline Saskatoon (Ag Biotech) & Canada & 6 & 31.7 & 2 & 38.3 & Pervasive Computing Cluster & Denmark & 6 & 51.8 & 5 & 31.4 \\
\hline Grenoble & France & 7 & 26.4 & 35 & 2.3 & Linz & Austria & 7 & 45.9 & 2 & 41.4 \\
\hline Human technology Styria & Austria & 8 & 25.6 & 5 & 20.1 & Oulu & Finland & 8 & 36.9 & 17 & 16.1 \\
\hline Mechatronics Cluster & Denmark & 9 & 22.9 & 11 & 12.8 & $\begin{array}{l}\text { Silicon Wadi (Jerusalem, Haifa, } \\
\text { Tel Aviv) }\end{array}$ & Israel & 9 & 35.9 & 39 & -19.2 \\
\hline Minnesota Medical Devices & USA & 10 & 22.1 & 14 & 11.4 & $\begin{array}{l}\text { Modelling and Simulation } \\
\text { cluster }\end{array}$ & USA & 10 & 34.7 & 15 & 16.9 \\
\hline Gottingen & Germany & 31 & 1.87 & 34 & 2.85 & ICT Cluster Dublin & Ireland & 31 & 7.1 & 25 & 7 \\
\hline Medical Valley Nuremberg & Germany & 32 & 1.5 & 29 & 6.3 & $\begin{array}{l}\text { Cluster } \\
\text { Informationstechnologien Tirol }\end{array}$ & Austria & 32 & 4.2 & 26 & 6.4 \\
\hline Heidelberg & Germany & 33 & 1.1 & 39 & -3.9 & GIS Cluster & Austria & 33 & 4.1 & 32 & 1.6 \\
\hline Beijing & China & 34 & 0.02 & 37 & 0.28 & Yokosuka Research Park & Japan & 34 & 3.5 & 38 & -2.3 \\
\hline Tsukuba & Japan & 35 & 0 & 4 & 23.6 & Brazilian Silicon Valley & Brazil & 35 & 2.7 & 1 & 44.6 \\
\hline Med-Tech cluster & Ireland & 36 & -1.7 & 6 & 16.1 & Tsukuba Science City & Japan & 36 & 1.8 & 35 & -0.1 \\
\hline Fiberoptic Valley & Sweden & 37 & -1.8 & 7 & 15.9 & Dommell Valley Eindhoven & Netherlands & 37 & 1.2 & 37 & -1.5 \\
\hline Tucson cluster & USA & 38 & -20.8 & 26 & 7.4 & Atlantic Technology Corridor & Ireland & 38 & 0 & 36 & -1.2 \\
\hline Micro- and Nanotechnology Horten & Norway & & -- & & -- & $\begin{array}{l}\text { Telecommunications in North } \\
\text { Jutland }\end{array}$ & Denmark & & -- & 16 & 16.9 \\
\hline Coimbra-Cantanhede's Biotech & Portugal & & -- & 12 & 12.7 & Bangalore & India & & -- & & -- \\
\hline
\end{tabular}

Source: Authors elaboration based on ORBIS database available from Bureau van Dijk. Note: -- means that data for the period was not available

Table 4 Ranking of business clusters by turnover growth

\begin{tabular}{|c|c|c|c|c|c|c|c|c|c|c|c|}
\hline \multirow[b]{2}{*}{ Name of cluster } & \multirow[b]{2}{*}{ Country } & \multicolumn{2}{|c|}{ Pre-recession } & \multicolumn{2}{|c|}{ Recession } & \multirow[b]{2}{*}{ Name of cluster } & \multirow[b]{2}{*}{ Country } & \multicolumn{2}{|c|}{ Pre-recession } & \multicolumn{2}{|c|}{ Recession } \\
\hline & & Rank & $\begin{array}{c}\% \\
\text { Growth } \\
\end{array}$ & Rank & $\begin{array}{c}\% \\
\text { Growth } \\
\end{array}$ & & & Rank & $\begin{array}{c}\% \\
\text { Growth }\end{array}$ & Rank & $\begin{array}{c}\% \\
\text { Growth }\end{array}$ \\
\hline Boston (Route 128) & USA & 1 & 108.2 & 5 & 26.7 & Cornell research district & USA & 1 & 94.3 & 18 & 15.5 \\
\hline Madison research district & USA & 2 & 93.2 & 17 & 15.7 & Beijing & China & 2 & 89.9 & 3 & 42.4 \\
\hline Tartu & Estonia & 3 & 73.5 & 7 & 25.6 & Pervasive Computing Cluster & Denmark & 3 & 87.8 & 21 & 13 \\
\hline Oslo Cancer Cluster & Norway & 4 & 71.5 & 16 & 16.7 & Oulu & Finland & 4 & 84.2 & 2 & 45.4 \\
\hline Oxfordshire bioscience cluster & UK & 5 & 70.3 & 18 & 13.6 & Silicon Valley & USA & 5 & 82.8 & 25 & 9 \\
\hline
\end{tabular}




\begin{tabular}{|c|c|c|c|c|c|c|c|c|c|c|c|}
\hline Uppsala BIO & Sweden & 6 & 69.6 & 26 & 9.4 & Amsterdam Alley & Netherlands & 6 & 82.3 & 24 & 11.9 \\
\hline Heidelberg & Germany & 7 & 67 & 28 & 6.2 & Espoo & Finland & 7 & 79.4 & 15 & 21.2 \\
\hline Mechatronics Cluster & Denmark & 8 & 62 & 1 & 67 & Kista & Sweden & 8 & 76.1 & 16 & 20.6 \\
\hline Life Science cluster (LISA) & Austria & 9 & 61.4 & 33 & -4 & Lisbon ICT cluster & Portugal & 9 & 74.7 & 4 & 41.3 \\
\hline Optical Tech Cluster & Germany & 10 & 56.1 & 34 & -5.1 & Dommell Valley Eindhoven & Netherlands & 10 & 74.5 & 40 & -18.3 \\
\hline Medical Valley Nuremberg & Germany & 31 & 33.9 & 37 & -10.2 & Austin ITC cluster & USA & 31 & 26.7 & 7 & 32 \\
\hline Bio-pharma cluster & Ireland & 32 & 33.6 & 10 & 23.3 & Tsukuba Science City & Japan & 32 & 25.4 & 30 & 4.3 \\
\hline Saskatoon (Ag Biotech) & Canada & 33 & 30.9 & 36 & -9.1 & Waterloo ICT cluster & Canada & 33 & 21.7 & 19 & 15.5 \\
\hline Cluster Life Sciences Innsbruck & Austria & 34 & 28.1 & 22 & 12.6 & Atlantic Technology Corridor & Ireland & 34 & 18.6 & 13 & 26.1 \\
\hline Tucson cluster & USA & 35 & 27.3 & 8 & 24.3 & Silicon Valley of Mexico & Mexico & 35 & 18.3 & 1 & 62.8 \\
\hline Minnesota Medical Devices & USA & 36 & 25.2 & 3 & 29.4 & Ottawa ICT cluster & Canada & 36 & 16.3 & 32 & 1.5 \\
\hline Montreal Biotech cluster & Canada & 37 & 19.6 & 27 & 8.7 & Silicon Glen & UK & 37 & 9.9 & 39 & -12.9 \\
\hline Ishikawa High-tech Sensing Cluster & Japan & 38 & 18.7 & 25 & 10 & Silicon Wadi & Israel & 38 & -20.2 & 10 & 28.4 \\
\hline Toyama Medical-Bio Cluster & Japan & 39 & 11.2 & 15 & 17.6 & Yokosuka Research Park & Japan & 39 & -30.8 & 22 & 12.9 \\
\hline Fiberoptic Valley & Sweden & 40 & 11.2 & 40 & -23 & $\begin{array}{l}\text { Telecommunications in North } \\
\text { Jutland }\end{array}$ & Denmark & & -- & 9 & 29.2 \\
\hline
\end{tabular}

Source: Authors elaboration based on ORBIS database available from Bureau van Dijk. Note: -- means that data for the period was not available

Table 5 Ranking of business clusters by profitability growth

\begin{tabular}{|c|c|c|c|c|c|c|c|c|c|c|c|}
\hline & & Pre-r & ession & $\operatorname{Rec}$ & ssion & & & Pre-r & ession & $\operatorname{Re}$ & ssion \\
\hline Name of cluster & Country & Rank & $\begin{array}{c}\% \\
\text { Growth }\end{array}$ & Rank & $\begin{array}{c}\% \\
\text { Growth } \\
\end{array}$ & Name of cluster & Country & Rank & $\begin{array}{c}\% \\
\text { Growth }\end{array}$ & Rank & $\begin{array}{c}\% \\
\text { Growth }\end{array}$ \\
\hline Human Technology Styria & Austria & 1 & 6.81 & 29 & -0.89 & Cap Digital Cluster & France & 1 & 2.6 & 24 & -0.72 \\
\hline Uppsala BIO & Sweden & 2 & 1.93 & 2 & 0.85 & Health care/Medical research & USA & 2 & 2.08 & & -- \\
\hline Fiberoptic Valley & Sweden & 3 & 1.35 & 21 & -0.45 & Silicon Valley of Germany & Germany & 3 & 1.38 & 6 & 0.27 \\
\hline Sao Paulo & Brazil & 4 & 1.12 & 1 & 1.56 & Tsukuba Science City & Japan & 4 & 1.29 & 9 & -0.02 \\
\hline Minnesota Medical Devices & USA & 5 & 0.87 & 4 & 0.7 & $\begin{array}{l}\text { Modelling and Simulation } \\
\text { cluster }\end{array}$ & USA & 5 & 0.84 & & -- \\
\hline Microlectronics cluster & Germany & 6 & 0.84 & 18 & -0.34 & Kista & Sweden & 6 & 0.81 & 18 & -0.61 \\
\hline Boston (Route 128) & USA & 7 & 0.79 & 3 & 0.79 & Silicon Valley of Mexico & Mexico & 7 & 0.39 & 5 & 0.6 \\
\hline
\end{tabular}




\begin{tabular}{|c|c|c|c|c|c|c|c|c|c|c|c|}
\hline Heidelberg & Germany & 8 & 0.75 & 8 & 0.06 & Dommell Valley Eindhoven & Netherlands & 8 & 0.31 & 28 & -1.27 \\
\hline Leuven & Belgium & 9 & 0.54 & 34 & -1.81 & Beijing & China & 9 & 0.3 & 13 & -0.24 \\
\hline Toyama Medical-Bio Cluster & Japan & 10 & 0.35 & 7 & 0.1 & Macquarie Park, Sydney & Australia & 10 & 0.22 & 7 & 0.09 \\
\hline Med-Tech cluster & Ireland & 31 & -0.65 & 30 & -0.93 & Bangalore & India & 31 & -1.77 & 29 & -1.32 \\
\hline Lisbon-Oeiras Bio-pharma cluster & Portugal & 32 & -0.87 & 19 & -0.39 & $\begin{array}{l}\text { Telecommunications in North } \\
\text { Jutland }\end{array}$ & Denmark & 32 & -2.21 & 20 & -0.64 \\
\hline Oslo Cancer Cluster & Norway & 33 & -0.91 & 20 & -0.45 & Bari ICT Cluster & Italy & 33 & -4.84 & 1 & 4.42 \\
\hline Cambridge Fen & UK & 34 & -1.04 & 25 & -0.69 & Twente ICT cluster & Netherlands & 34 & -12.6 & 30 & -1.8 \\
\hline Optical Tech Cluster & Germany & 35 & -1.57 & 27 & -0.79 & Cornell research district & USA & & -- & & -- \\
\hline $\begin{array}{l}\text { Coimbra-Cantanhede's Biotech } \\
\text { cluster }\end{array}$ & Portugal & 36 & -1.91 & 6 & 0.25 & Silicon Valley & USA & & -- & & -- \\
\hline Tartu & Estonia & 37 & -4.12 & 33 & -1.13 & Linz & Austria & & -- & & -- \\
\hline Cluster Life Sciences Innsbruck & Austria & & -- & & -- & Ottawa ICT cluster & Canada & & -- & & -- \\
\hline Saskatoon (Ag Biotech) & Canada & & -- & & -- & $\begin{array}{l}\text { Cluster } \\
\text { Informationstechnologien Tirol }\end{array}$ & Austria & & -- & & -- \\
\hline Madison research district & USA & & -- & & -- & GIS Cluster & Austria & & -- & & -- \\
\hline
\end{tabular}

Source: Authors elaboration based on ORBIS database available from Bureau van Dijk. Note: -- means that data for the period was not available

Table 6 Ranking of business clusters by liquidity ratio

\begin{tabular}{|c|c|c|c|c|c|c|c|c|c|c|c|}
\hline \multirow[b]{2}{*}{ Name of cluster } & \multirow[b]{2}{*}{ Country } & \multicolumn{2}{|c|}{ Pre-recession } & \multicolumn{2}{|c|}{ Recession } & \multirow[b]{2}{*}{ Name of cluster } & \multirow[b]{2}{*}{ Country } & \multicolumn{2}{|c|}{ Pre-recession } & \multicolumn{2}{|c|}{ Recession } \\
\hline & & Rank & $\begin{array}{c}\% \\
\text { Growth } \\
\end{array}$ & Rank & $\begin{array}{c}\% \\
\text { Growth } \\
\end{array}$ & & & Rank & $\begin{array}{c}\% \\
\text { Growth } \\
\end{array}$ & Rank & $\begin{array}{c}\% \\
\text { Growth }\end{array}$ \\
\hline Instrumentation Trondheim & Norway & 1 & 3.21 & 27 & 0.16 & Twente ICT cluster & Netherlands & 1 & 2.38 & 1 & 6.61 \\
\hline Tartu & Estonia & 2 & 1.06 & 1 & 1.59 & Linz & Austria & 2 & 1.8 & 25 & 0.22 \\
\hline Human technology Styria & Austria & 3 & 1.05 & 2 & 1.05 & Atlantic Technology Corridor & Ireland & 3 & 1.37 & 16 & 0.39 \\
\hline Life Science cluster (LISA) & Austria & 4 & 0.99 & 13 & 0.41 & Austin ITC cluster & USA & 4 & 1.3 & 23 & 0.26 \\
\hline Optical Tech Cluster & Germany & 5 & 0.85 & 24 & 0.2 & GIS Cluster & Austria & 5 & 0.99 & 20 & 0.34 \\
\hline Tucson cluster & USA & 6 & 0.74 & 16 & 0.34 & Daedoek Science Town & Korea & 6 & 0.78 & 3 & 0.92 \\
\hline Microlectronics cluster & Germany & 7 & 0.74 & 3 & 0.94 & Macquarie Park, Sydney & Australia & 7 & 0.77 & 32 & 0.02 \\
\hline Med-Tech cluster & Ireland & 8 & 0.7 & 8 & 0.52 & Tsukuba Science City & Japan & 8 & 0.69 & 22 & 0.29 \\
\hline Bio-pharma cluster & Ireland & 9 & 0.69 & 9 & 0.5 & Silicon Valley of Germany & Germany & 9 & 0.68 & 12 & 0.43 \\
\hline Lisbon-Oeiras Bio-pharma cluster & Portugal & 10 & 0.59 & 6 & 0.6 & $\begin{array}{l}\text { Cluster } \\
\text { Informationstechnologien Tirol }\end{array}$ & Austria & 10 & 0.65 & 14 & 0.41 \\
\hline
\end{tabular}




\begin{tabular}{|c|c|c|c|c|c|c|c|c|c|c|c|}
\hline Grenoble & France & 31 & 0.06 & 34 & 0.06 & Beijing & China & 31 & 0.1 & 28 & 0.12 \\
\hline Toulouse aerospace cluster & France & 32 & 0.03 & 23 & 0.22 & Brazilian Silicon Valley & Brazil & 32 & 0.08 & 36 & -0.28 \\
\hline Lyon biotech cluster & France & 33 & -0.02 & 31 & 0.1 & Kansai Science City & Japan & 33 & 0.02 & 30 & 0.03 \\
\hline Toyama Medical-Bio Cluster & Japan & 34 & -0.02 & 36 & -0.01 & Silicon Wadi & Israel & 34 & -0.09 & 35 & -0.21 \\
\hline Ishikawa High-tech Sensing Cluster & Japan & 35 & -0.06 & 33 & 0.07 & Pervasive Computing Cluster & Denmark & 35 & -0.31 & 9 & 0.54 \\
\hline Micro- and Nanotechnology Horten & Norway & 36 & -0.07 & 28 & 0.16 & $\begin{array}{l}\text { Telecommunications in North } \\
\text { Jutland }\end{array}$ & Denmark & & -- & 33 & -0.07 \\
\hline Montreal Biotech cluster & Canada & 37 & -0.27 & 11 & 0.45 & Cornell research district & USA & & -- & & -- \\
\hline Mechatronics Cluster & Denmark & 38 & -0.3 & 18 & 0.3 & Silicon Valley & USA & & -- & & -- \\
\hline Saskatoon (Ag Biotech) & Canada & & -- & & -- & $\begin{array}{l}\text { Modelling and Simulation } \\
\text { cluster }\end{array}$ & USA & & -- & & -- \\
\hline Madison research district & USA & & -- & & -- & Ottawa ICT cluster & Canada & & -- & & -- \\
\hline
\end{tabular}

Source: Authors elaboration based on ORBIS database available from Bureau van Dijk. Note: -- means that data for the period was not available

Table 7 Ranking of business clusters by solvency ratio

\begin{tabular}{|c|c|c|c|c|c|c|c|c|c|c|c|}
\hline \multirow[b]{2}{*}{ Name of cluster } & \multirow[b]{2}{*}{ Country } & \multicolumn{2}{|c|}{ Pre-recession } & \multicolumn{2}{|c|}{ Recession } & \multirow[b]{2}{*}{ Name of cluster } & \multirow[b]{2}{*}{ Country } & \multicolumn{2}{|c|}{ Pre-recession } & \multicolumn{2}{|c|}{ Recession } \\
\hline & & Rank & $\begin{array}{c}\% \\
\text { Growth }\end{array}$ & Rank & $\begin{array}{c}\% \\
\text { Growth }\end{array}$ & & & Rank & $\begin{array}{c}\% \\
\text { Growth }\end{array}$ & Rank & $\begin{array}{c}\% \\
\text { Growth }\end{array}$ \\
\hline Cluster Life Sciences Innsbruck & Austria & 1 & 1.37 & 13 & 0.1 & Macquarie Park, Sydney & Australia & 1 & 3.25 & 14 & 0.1 \\
\hline Med-Tech cluster & Ireland & 2 & 0.31 & 9 & 0.13 & GIS Cluster & Austria & 2 & 1.26 & 15 & 0.1 \\
\hline Bio-pharma cluster & Ireland & 3 & 0.3 & 6 & 0.19 & Tsukuba Science City & Japan & 3 & 1.03 & 3 & 0.54 \\
\hline Gottingen & Germany & 4 & 0.21 & 29 & -0.02 & Information processing cluster & Spain & 4 & 0.49 & 10 & 0.31 \\
\hline Medicon Valley & Sweden & 5 & 0.16 & 16 & 0.08 & ICT Cluster Dublin & Ireland & 5 & 0.42 & 9 & 0.33 \\
\hline Gothenburg Bio cluster & Sweden & 6 & 0.15 & 12 & 0.11 & $\begin{array}{l}\text { Cluster } \\
\text { Informationstechnologien Tirol }\end{array}$ & Austria & 6 & 0.4 & 20 & 0.02 \\
\hline Toyama Medical-Bio Cluster & Japan & 7 & 0.15 & 26 & -0.01 & Atlantic Technology Corridor & Ireland & 7 & 0.37 & 35 & -0.2 \\
\hline Optical Tech Cluster & Germany & 8 & 0.13 & 35 & -0.14 & Twente ICT cluster & Netherlands & 8 & 0.34 & 23 & 0.01 \\
\hline Fiberoptic Valley & Sweden & 9 & 0.12 & 17 & 0.06 & Kista & Sweden & 9 & 0.27 & 7 & 0.37 \\
\hline Ishikawa High-tech Sensing Cluster & Japan & 10 & 0.12 & 27 & -0.01 & Yokosuka Research Park & Japan & 10 & 0.2 & 25 & 0 \\
\hline Lyon biotech cluster & France & 31 & -0.11 & 7 & 0.18 & Silicon Wadi & Israel & 31 & -0.02 & 36 & -1.57 \\
\hline Medical Valley Nuremberg & Germany & 32 & -0.12 & 2 & 0.29 & Silicon Valley of Mexico & Mexico & 32 & -0.06 & 2 & 0.72 \\
\hline
\end{tabular}




\begin{tabular}{|c|c|c|c|c|c|c|c|c|c|c|c|}
\hline Micro- and Nanotechnology Horten & Norway & 33 & -0.13 & 10 & 0.11 & Beijing & China & 33 & -0.06 & 29 & -0.02 \\
\hline Oxfordshire bioscience cluster & UK & 34 & -0.16 & 36 & -0.26 & Silicon Valley of Germany & Germany & 34 & -0.07 & 18 & 0.03 \\
\hline Mechatronics Cluster & Denmark & 35 & -0.16 & 37 & -0.52 & Oulu & Finland & 35 & -0.11 & 34 & -0.13 \\
\hline Montreal Biotech cluster & Canada & 35 & -0.26 & 11 & 0.11 & Pervasive Computing Cluster & Denmark & 36 & -1.92 & 8 & 0.34 \\
\hline Boston (Route 128) & USA & 36 & -0.49 & 38 & -0.61 & Cornell research district & USA & & -- & & -- \\
\hline Biotech cluster & Portugal & 37 & -0.62 & 19 & 0.05 & Silicon Valley & USA & & -- & & -- \\
\hline Lisbon-Oeiras Bio-pharma cluster & Portugal & 38 & -1.05 & 28 & -0.01 & $\begin{array}{l}\text { Modelling and Simulation } \\
\text { cluster }\end{array}$ & USA & & -- & & -- \\
\hline Saskatoon (Ag Biotech) & Canada & & -- & & -- & Ottawa ICT cluster & Canada & & -- & & -- \\
\hline
\end{tabular}

Source: Authors elaboration based on ORBIS database available from Bureau van Dijk. Note: -- means that data for the period was not available

Table 8: Evidence (Prevalence of Resilience)

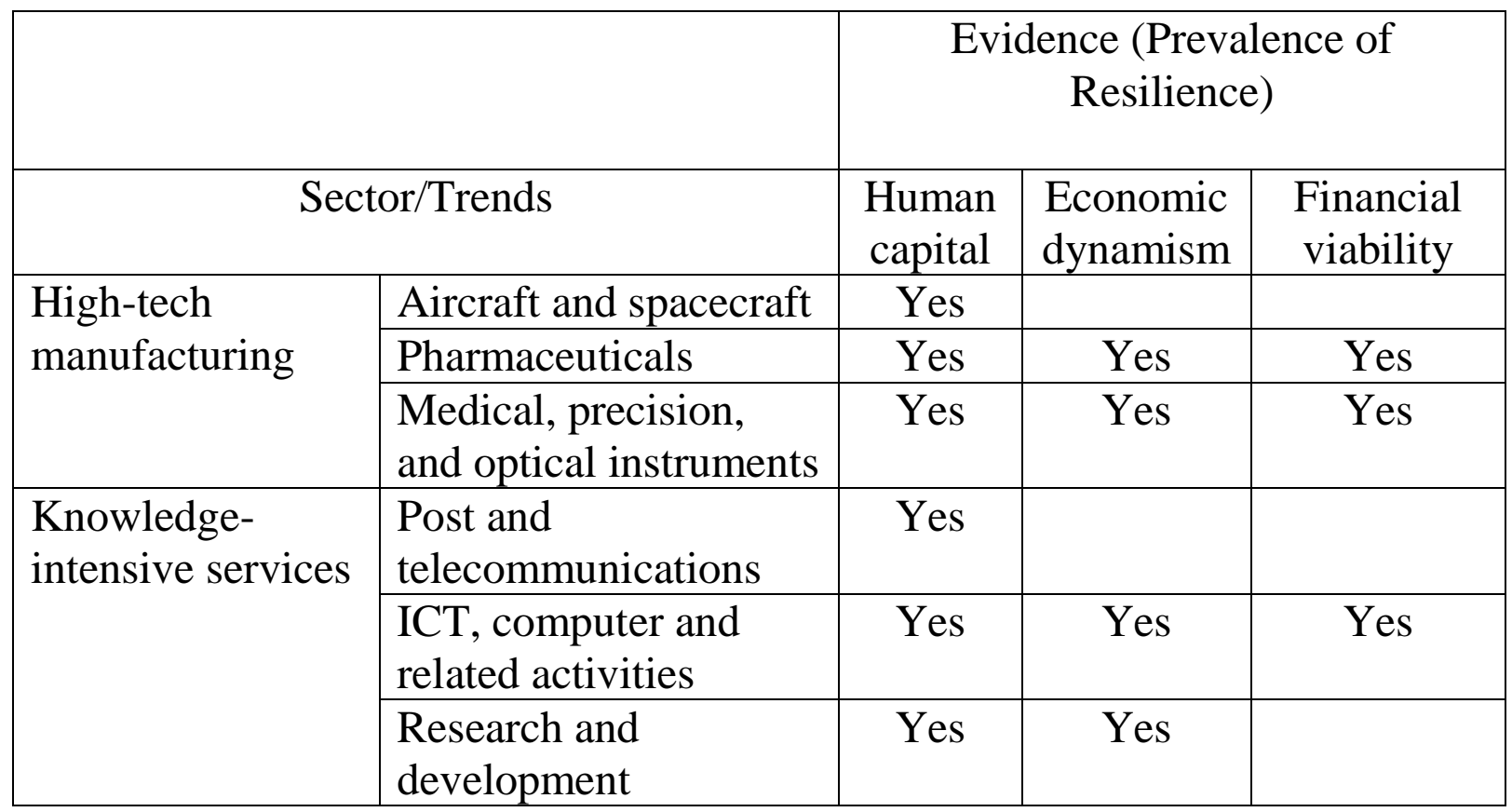


